\title{
Evaluating runoff water quality and ammonia volatilization in three turkey litter application methods
}

\author{
Michael Dale Shamblin \\ West Virginia University
}

Follow this and additional works at: https://researchrepository.wvu.edu/etd

\section{Recommended Citation}

Shamblin, Michael Dale, "Evaluating runoff water quality and ammonia volatilization in three turkey litter application methods" (2003). Graduate Theses, Dissertations, and Problem Reports. 1714.

https://researchrepository.wvu.edu/etd/1714

This Thesis is protected by copyright and/or related rights. It has been brought to you by the The Research Repository @ WVU with permission from the rights-holder(s). You are free to use this Thesis in any way that is permitted by the copyright and related rights legislation that applies to your use. For other uses you must obtain permission from the rights-holder(s) directly, unless additional rights are indicated by a Creative Commons license in the record and/ or on the work itself. This Thesis has been accepted for inclusion in WVU Graduate Theses, Dissertations, and Problem Reports collection by an authorized administrator of The Research Repository @ WVU. For more information, please contact researchrepository@mail.wvu.edu. 


\section{Evaluating Runoff Water Quality and Ammonia Volatilization in Three Turkey Litter Application Methods}

Michael D. Shamblin

Thesis submitted to the Davis College of Agriculture, Forestry, and Consumer Sciences at West Virginia University in partial fulfillment of the requirements

for the degree of

Master of Science
in
Agriculture and Environmental Education

Dr. Sanjay B. Shah, Ph.D.

Dr. Stacy A. Gartin, Ph.D.

Dr. Devinder K. Bhumbla, Ph.D.

Dr. Harry N. Boone, Ph.D.

Division of Resource Managment

Morgantown, West Virginia

2002

Keywords: Poultry Litter, Manure, Surface Runoff, Nutrient Management, Surface Banding, Incorporated Banding 


\section{Abstract \\ Evaluating Runoff Water Quality and Ammonia Volatilization in Three Turkey Litter Application Methods}

\section{Michael D. Shamblin}

Poultry litter is an important nutrient source in crop production. However, the traditional practice of broadcasting poultry litter on the soil surface could result in nutrient losses in runoff as well as substantial ammonia volatilization losses, which could adversely affect both the environment and agricultural productivity. This research compared nutrient runoff (natural and simulated) losses on $1 \mathrm{~m} \mathrm{X} 2 \mathrm{~m}$ plots and ammonia volatilization from different turkey litter application methods (broadcast, surface-banded, incorporated band, and control) applied in triplicate. No siginificant differences were observed between any of the treatments in any of the runoff constituents measured. Over three runoff events (two simulated) spanning $9 \mathrm{~d}$, ammonium and inorganic phosphorus losses in runoff were substantially lower in the incorporated band treatment than in the broadcast and band applications. Compared with the broadcast and band applications, ammonia volatilization losses from incorporated bands were reduced five-fold over $11 \mathrm{~d}$. Ammonia trapping efficiency of low-cost, passive ammonia samplers were also evaluated. Compared with broadcast application, incorporating surfacebanded poultry litter could reduce nutrient losses into the environment which could be particularly useful in conservation tillage. 


\section{Acknowledgements}

By far, this is the hardest endeavor that I have ever pursued. My sincerest gratitude goes to Dr. Sanjay Shah for his patient guidance throughout the duration of this research and thesis. His caring attitude, eagerness to help students, and agricultural knowledge base has created a challenging, yet enjoyable graduate career.

I also extend sincere thanks to Dr. Devinder Bhumbla. Without the use of his resources and knowledge of runoff studies, this research would not be possible. Thanks also to the other members of my graduate committee, Dr. Stacy Gartin and Dr. Harry Boone. The sound instruction and advice that you have provided has not only contributed to my professional growth, but influences other students on a daily basis as well.

Thanks also to the farm technicians at the Animal and Veterinary Science Farm for the cooperation and help provided in preparing the research site and the Rumen Fermentation Laboratory staff for their efficiency in analysis of samples.

To my fellow graduate students and friends, I extend thanks for giving the support to move forward when things looked bleak. A kind word and a listening ear are sometimes the best medicine.

To my family, I express my gratitude for instilling in me a strong work ethic, providing encouragement, and always standing behind my decisions. All have been very useful throughout the duration of this study. Strong upbringing makes strong character, and close families keep us that way. 


\section{Table of Contents}

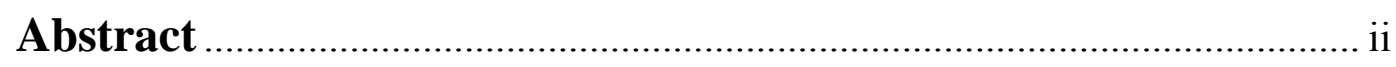

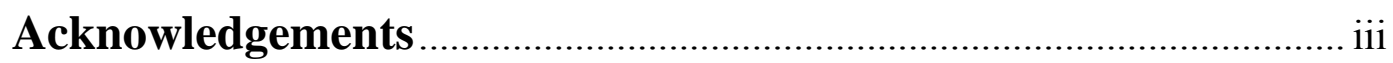

Table of Contents .......................................................................... iv

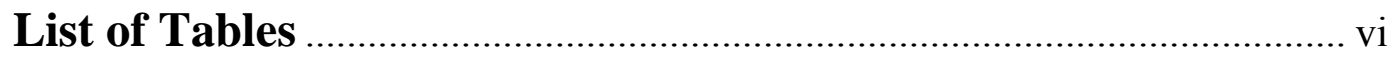

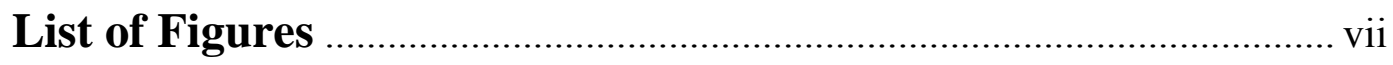

\section{Chapter 1}

Introduction

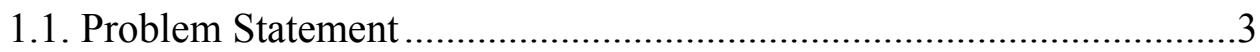

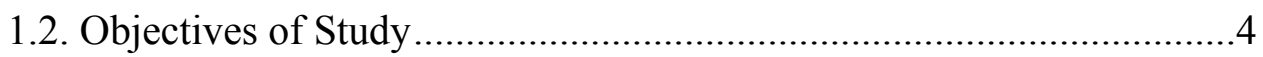

\section{Chapter 2}

Review of Literature

2.1. Runoff Water Quality Impacts of Poultry Litter Application................5

2.2. Ammonia Volatilization From Poultry Litter Application .....................6

\section{Chapter 3}

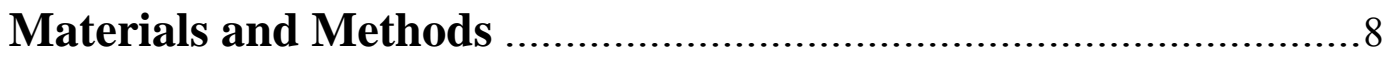

3.1. Field Site and Description.................................................................

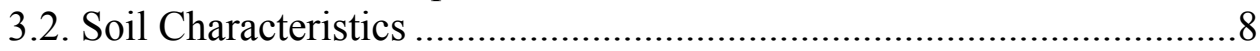

3.3. Treatment Design............................................................................

3.4. Statistical Methods.......................................................................... 10

3.5. Turkey Litter Characteristics ………………………………….......10

3.6. Field Layout ....................................................................................11

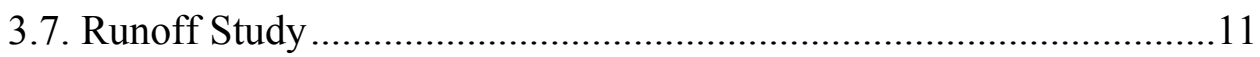

3.7.1. Field Operations ........................................................................11

3.7.2. Rainfall Simulation ..............................................................13

3.7.3. Runoff Collection...................................................................14

3.7.4. Analysis of Runoff Constituents .................................................15

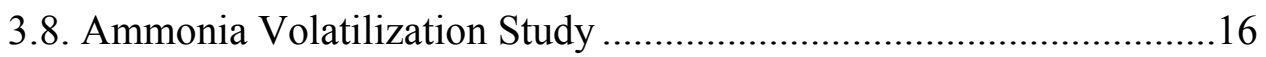

3.8.1. Ammonia Sampler Design and Fabrication................................16

3.8.2. Sampler Efficiency Evaluation .................................................17

3.8.3. Field Operations.....................................................................18

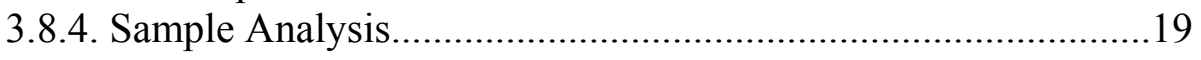




\section{Chapter 4}

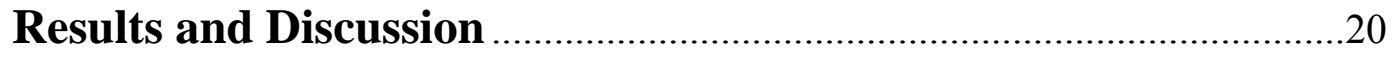

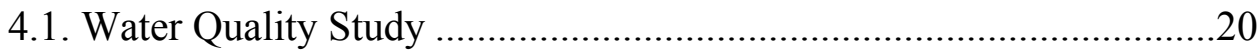

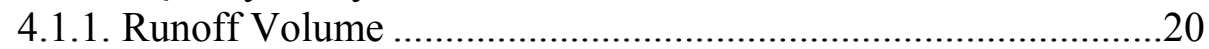

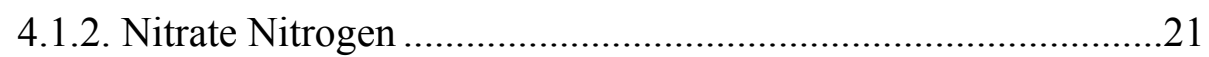

4.1.3. Ammoniacal Nitrogen.......................................................22

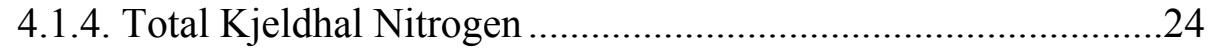

4.1.5. Dissolved Reactive Phosphorus ..............................................25

4.1.6. Sediment Bound Reactive Phosphorus ...................................26

4.1.7.Total Phosphorus ..............................................................27

4.1.8. Total Suspended Solids ........................................................29

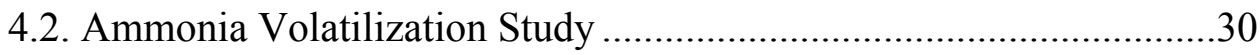

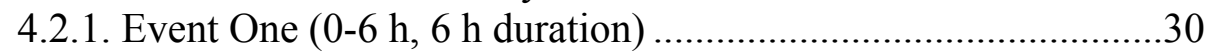

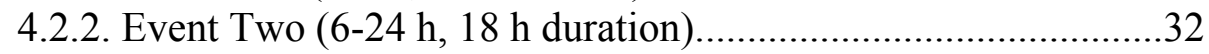

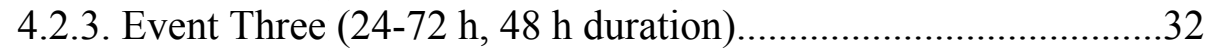

4.2.4. Event Four (72-120 h, 48 h duration) .....................................33

4.2.5. Event Five (120 h-168 h, 48 h duration)................................33

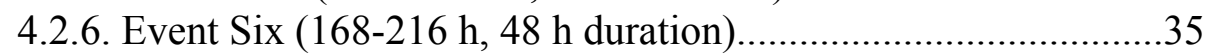

4.2.7. Event Seven (216-264 h, 48 h duration) .................................35

4.2.8. Total Ammonia Volatilization Losses and Trends ...................37

4.3. Environmental Impacts of Turkey Litter Application .....................40

\section{Chapter 5}

Summary and Conclusions......................................................................4

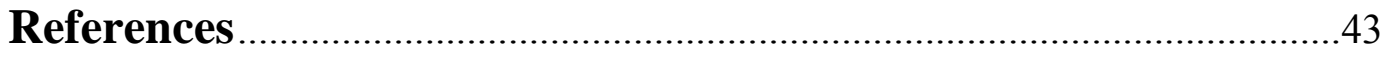

Appendix A

Constituent Concentrations in Runoff ........................................................46

Appendix B

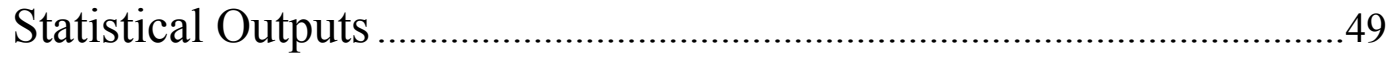

\section{Appendix C}

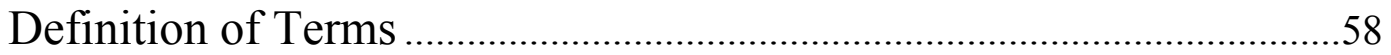




\section{List Of Tables}

Table 3.1.

Selected Physical and Chemical Properties of the Soil at the Field Site.

Table 3.2.

Physical and Chemical Properties of the Turkey Litter

Table 3.3.

Analytical Methods Used in Testing Runoff Constituents

Table 4.1.

Treatment Effect on Runoff Volume: Results of the Statistical Analysis at $\alpha=0.05$

Table 4.2.

Treatment Effect on $\mathrm{NO}_{3}{ }^{-}-\mathrm{N}$ : Results of Statistical Analysis at $\alpha=0.05$

Table 4.3.

Treatment Effect on Ammoniacal - N: Results of Statistical Analysis at $\alpha=0.05$

Table 4.4.

Treatment Effect on TKN: Results of Statistical Analysis at $\alpha=0.05$

Table 4.5.

Treatment Effect on DRP: Results of Statistical Analysis at $\alpha=0.05$.

Table 4.6.

Treatment Effect on SBRP: Results of Statistical Analysis at $\alpha=0.05$

Table 4.7.

Treatment Effect on TP: Results of Statistical Analysis at $\alpha=0.05$.....

Table 4.8.

Treatment Effect on TSS: Results of Statistical Analysis at $\alpha=0.05$

Table 4.9.

Efficiency of $\mathrm{NH}_{3}$ Samplers 


\section{List of Figures}

Figure 3.1.

Layout of field site.

Figure 3.2.

Natural rainfall during the runoff study

Figure 3.3.

Ammonia sampler design

Figure 4.1.

Ammonia volatilization during event one (0-6 h, 6- $h$ duration), event two (6-24 h, 18-h duration), and event three (24-72 h, 48-h duration)

Figure 4.2.

Ammonia volatilization during event four (72-120 h, 48-h duration), event five (120-168 $h, 48-h$ duration), and event six (168-216h, 48-h duration)

Figure 4.3.

Ammonia volatilization during event seven (216-264 h, 48-h duration) and total $\mathrm{NH}_{3}$ volatilization losses.

Figure 4.4.

Ammonia loss trend for duration of $\mathrm{NH}_{3}$ volatilization study..... 38

Figure 4.5.

Soil surface temperatures under ammonia sampler and exposed to sunlight 40 


\section{Chapter 1}

\section{Introduction}

The poultry industry in West Virginia is steadily increasing. Poultry production is a major contributor to West Virginia's agricultural sector, producing over half of the total agricultural income. In 2001, poultry production contributed $\$ 143.6$ million to West Virginia's economy, up $15 \%$ from 2000 (WVASS, 2002). In 2001, US poultry production contributed $\$ 16.7$ billion to the economy, up $19 \%$ from 2000 (WVASS, 2002). The poultry industry is not only a major contributor to the economy, but is steadily increasing across the country. Commercial poultry production generates large amounts of waste in the form of poultry litter. Poultry litter is a mixture of bedding material, such as, wood chips or shavings or straw, and poultry manure, as well as feathers, feed, and water. In West Virginia, 150,000 to 350,000 tons of poultry litter are produced annually (Ferguson, 1997).

Poultry litter is widely used as a nutrient source for nitrogen $(\mathrm{N})$, phosphorus $(\mathrm{P})$ and potassium (K). One metric ton of poultry litter typically contains $32.5 \mathrm{~kg}$ of N, $16.5 \mathrm{~kg}$ of P, and $13.5 \mathrm{~kg}$ of $\mathrm{K}$. Increases in crop production and soil productivity have been documented with the use of poultry litter (Wood, Wood, Yoo, and Yoon, 1996).

The environmental consequences of livestock production and waste management are of increasing public concern. Over one quarter of US surface water contamination from agriculture has been attributed to livestock waste (Innes, 1999). Nutrients lost through volatilization, runoff, and leaching are areas of concern when land applying poultry litter. Two of the major problems facing the poultry industry with respect to waste management are non-point source P runoff and high levels of atmospheric ammonia ( $\left.\mathrm{NH}_{3}\right)$ (Moore, Daniel, and Edwards, 1999). 
Since poultry litter is an inexpensive source of $\mathrm{N}$, it has traditionally been applied based on $\mathrm{N}$ content with little regard to $\mathrm{P}$ (Gallimore et al., 1999) frequently resulting in overapplication of P (Xingguo and Duane, 1996). Corn nutrient requirements are $191 \mathrm{~kg}$ of N and $39 \mathrm{~kg}$ of P per hectare for $9.8 \mathrm{Mg} / \mathrm{ha}$ corn (Tisdale, Nelson, Beaton, and Havlin, 1993). If the $\mathrm{N}$ requirement is met with the use of poultry litter, over-application of $\mathrm{P}$ by 2.5 times would result, based on N/P ratio in typical poultry litter. Over-application of $\mathrm{N}$ and $\mathrm{P}$ would be even greater when litter disposal is the primary objective with crop considerations being of secondary importance (Nichols et al.,1994).

Concerns about the amount of $\mathrm{P}$ entering aquatic habitats have increased, especially in the eastern U.S. (Hays, 1994). Poultry litter application has been shown to result in high P runoff even when applied at recommended rates (Moore et al., 1999). Over application of P has a negative impact on aquatic habitats since $\mathrm{P}$ is the primary limiting agent for freshwater algae and plants in some water bodies. When other environmental conditions (for example, threshold inorganic-N concentrations) are met, $\mathrm{P}$ loadings to water bodies can contribute to massive algal blooms (eutrophication), leading to depletion of dissolved oxygen which could result in fish kills.

Nitrogen in poultry litter can supply the crop's $\mathrm{N}$ requirement, but can contribute to pollution if lost into the environment. Ammonia volatilization could increase atmospheric levels of N, resulting in increased acid rain (Marshal, Wood, and Guertal, 1998). Ammonia lost through volatilization can be of economic importance because it could lead to substantial losses of N (Cabrera, Chiang, Merka, Thompson, and Pancorbo, 1993).

In order to safeguard both the environment as well as a viable poultry industry, poultry litter management must be a priority. Improved poultry litter application methods could help in 
conserving nutrients in the field, and thus, could be an important tool in safeguarding water and air qualities.

\subsection{Problem Statement}

Broadcasting poultry litter on the soil surface has been a common method of waste management. Ease of disposal and low application costs makes broadcasting the method of choice when applying poultry litter. However, broadcast application may not be the most suitable method for retaining nutrients in the field. Ammonia volatilization can occur more readily under broadcast conditions. Nutrients in the broadcast litter can be carried off in runoff. Alternative methods of application, such as, surface banding (dribbling) have been found to be promising. Bittman, Kowalenko, Hunt and Schmidt (1999) investigated the effects of broadcast and banded liquid dairy manure on tall fescue yields and N uptake. Bittman et. al. (1999) reported that banded application gave higher fescue yields than broadcasting, especially in summer. Bittman et al. (1999) hypothesized that reduced ammonia volatilization due to surface banding could have improved plant yield. Increased plant uptake of $\mathrm{N}$ in the banded application could reduce $\mathrm{N}$ available for loss and decreases potential environmental degradation.

Phosphorus and $\mathrm{N}$ losses can degrade water bodies, reducing productivity and aesthetics. Phosphorus losses in the Potomac River Valley have been blamed for the algal blooms and fish kills in the Potomac River and Chesapeake Bay.

Innovative poultry litter application methods could significantly reduce nutrient losses into the environment. Compared with broadcasting, incorporation of bands could result in reduced nutrient losses in runoff and ammonia volatilization. Hence, banding and incorporated banding of poultry litter could be more suitable for conserving nutrients for crop growth and reducing pollution. 


\subsection{Objectives of Study}

The objective of this study is to evaluate the environmental impacts of different turkey litter application methods (broadcast, band, and incorporated band) through the following specific objectives:

I. to evaluate the effects of different turkey litter application methods on total runoff volume as well as nitrate- $\mathrm{N}\left(\mathrm{NO}_{3}{ }^{-}-\mathrm{N}\right)$, ammoniacal-N $\left(\mathrm{NH}_{4}{ }^{+}-\mathrm{N}+\mathrm{NH}_{3}-\mathrm{N}\right)$, total Kjeldahl $\mathrm{N}(\mathrm{TKN})$, total $\mathrm{P}(\mathrm{TP})$, dissolved reactive $\mathrm{P}(\mathrm{DRP})$, sediment bound reactive $\mathrm{P}$ (SBRP), and total suspended solids (TSS) concentrations in surface runoff, and,

II. to evaluate $\mathrm{NH}_{3}$ volatilization losses from the three turkey litter application methods. 


\section{Chapter 2}

\section{Review of Literature}

Decreasing nutrient loss from agricultural lands is of concern, not only to enhance or maintain crop productivity but also to reduce environmental degradation. When nutrient sources are broadcast on the soil surface, substantial amounts of nutrients can be lost through surface runoff and ammonia volatilization. Selected studies comparing poultry waste application methods with regard to runoff water quality and ammonia volatilization are discussed below.

\subsection{Runoff Water Quality Impacts of Poultry Litter Application}

Nichols, Daniel, and Edwards (1994) studied the nutrient runoff concentrations in tall fescue after the application of broadcast and broadcast incorporated poultry litter as well as broadcast and broadcast incorporated inorganic fertilizer. Poultry litter and inorganic fertilizer were applied $218 \mathrm{~kg} \mathrm{~N} / \mathrm{ha}$ and $87 \mathrm{~kg} \mathrm{P} / \mathrm{ha}$. In the incorporated plots, poultry litter was tilled into the soil to a depth of 2-3 cm with a rotary tiller. Total Kjeldahl $\mathrm{N}(\mathrm{TKN})$, ammoniacal-N, $\mathrm{NO}_{3}^{-}-$ $\mathrm{N}$, TP, orthophosphate (ortho $-\mathrm{P}$ ), chemical oxygen demand (COD) and TSS concentrations were examined in runoff. With poultry litter, no significant differences were observed between broadcast and broadcast incorporated treatments. Nichols, Daniel, and Edwards (1994) hypothesized that while deeper incorporation would have damaged the fescue cover, it could have been more effective in retaining nutrients and increasing plant yields.

Edwards and Daniel (1992), surface-applied (broadcasted) poultry manure slurry to grassed areas and examined runoff $1 \mathrm{~d}$ after application. Poultry manure slurry was applied at rates of 0,220 , and $879 \mathrm{~kg}-\mathrm{N} / \mathrm{ha}$ to plots with established fescue on Captina silt loam. Rainfall was applied at 5 or $10 \mathrm{~cm} / \mathrm{h}$. Runoff samples were analyzed for TKN, $\mathrm{NH}_{3}-\mathrm{N}, \mathrm{NO}_{3}^{-}-\mathrm{N}$, total $\mathrm{P}$, 
DRP, COD, TSS, and electrical conductivity. Slurry application rate had a significant effect on runoff concentrations of all manure constituents except $\mathrm{NO}_{3}{ }^{-}-\mathrm{N}$. All constituents examined in the study except $\mathrm{NO}_{3}-\mathrm{N}$ increased linearly with slurry application rate. Mass loss of $\mathrm{NO}_{3}-\mathrm{N}$ was affected only by rainfall intensity. Edwards and Daniel (1992) concluded that rainfall events occurring soon after surface application of poultry litter produced significantly higher levels of runoff constituents compared with untreated plots.

\subsection{Ammonia Volatilization from Poultry Litter Application}

Marshal et al. (1998) examined NH3 volatilization from tall fescue fertilized with broiler litter. Litter was applied at a rate of $70 \mathrm{~kg}$ available N/ha. Ammonia was sampled with passive samplers using a micrometeorological mass balance method. Samplers consisted of glass tubes coated with oxalic acid held on 3-m tall masts at central locations on collection plots. Samples were collected on a daily basis for $14 \mathrm{~d}$ starting immediately after litter application. Marshal et al. (1998) reported a sharp increase in ammonia volatilization 1-3 d after application, with rates rapidly decreasing to normal levels within $10 \mathrm{~d}$. Marshal et al. (1998) concluded that $\mathrm{NH}_{3}$ volatilization due to land application of broiler litter was unlikely to cause significant environmental degradation.

Nathan and Malzer (1994) studied the dynamics of $\mathrm{NH}_{3}$ volatilization from broadcast and incorporated turkey manure. Turkey manure at $16 \mathrm{Mg} /$ ha was surface applied or incorporated immediately with a fork to Estherville sandy loam soil. Soil temperature, air temperature, wind speed, and relative humidity were also measured. Ammonia volatilization was measured using samplers (24 cm diameter PVC cylinders), randomly placed on the plots and pressed $14 \mathrm{~cm}$ into the soil. Ammonia samples were taken every $3 \mathrm{~h}$ for 20 minutes. Air was drawn from the 
sampler using a vacuum pump at $-50 \mathrm{kPa}$ and forced into boric acid solution. During times when samples were not taken, the samplers were left uncapped. Nathan and Malzer (1994) concluded that $\mathrm{NH}_{3}$ losses were 23 times greater for surface-applied manure than for incorporated manure. Positive correlations were seen between $\mathrm{NH}_{3}$ volatilization and soil temperature, atmospheric temperature, and wind speed. Relative humidity was generally negatively correlated with $\mathrm{NH}_{3}$ volatilization.

Researchers generally agree that adequate incorporation of nutrients is an important tool in conserving $\mathrm{N}$ and $\mathrm{P}$. Broadcast applications are consistently proven to be a less desirable form of application for conserving nutrients. While the environmental impacts of different poultry litter application methods have been evaluated in pastureland, there is need for such a study in conservation tillage corn, particularly because of heavy residue cover and difficulties in incorporating nutrients into the soil. Further research on the environmental impacts of surface banding poultry litter could not be located. Innovative application methods, such as, banding and incorporating bands of poultry litter offer the potential to reduce nutrient losses into the environment, thereby, increasing nutrient availability for crop uptake. 


\section{Chapter 3}

\section{Materials and Methods}

\subsection{Field Site and Description}

The field site for conducting runoff and ammonia volatilization studies using turkey litter was identified at West Virginia University’s Animal and Veterinary Sciences Farm in Morgantown, WV. The field site had been under conservation tillage corn in fall, 2001, that had been followed by wheat as cover crop which had been planted after discing in the winter of 2001-2002. While the main slope of the field site ranged from $8-12 \%$, the cross slope was determined to be less than $2 \%$.

Prior to starting the fieldwork, the wheat cover crop was chemically killed by staff of the West Virginia University Animal and Veterinary Sciences Farm on May 26, 2002. Because of difficulty in conducting fieldwork, the killed cover crop was cut with a sickle bar mower to a height of about $9 \mathrm{~cm}$ (3.5 in.) on May 28, 2002, and allowed to dry for 2 days. Upon drying, the wheat crop was raked, baled, and removed from the field site.

\subsection{Soil Characteristics}

Soil type at the field site was Zoar silt loam (clayey, mixed, mesic, Aquic Hapludults) (SCS, 1982). Zoar silt loam soils are deep, moderately well drained soils formed in acid slackwater deposits of old stream sediments. Zoar soils are typically found along terraces of the Cheat, Monongahela, Tygart Valley, and West Fork Rivers and Dunkard Creek (SCS, 1982). Zoar soils are strongly to very strongly acid. Depth to bedrock on typical Zoar silt loam soil is in excess of $150 \mathrm{~cm}$. 
Soil samples were collected at a depth of $5 \mathrm{~cm}(2 \mathrm{in}$.$) , using a tube sampler at multiple$ points between plots (to avoid disturbing the plots). Samples were frozen prior to analysis. The soil samples were analyzed for selected physical and chemical properties (see Table 3.1).

Table 3.1. Selected Physical and Chemical Properties of the Soil at the Field Site ${ }^{[a]}$

\begin{tabular}{|c|c|c|c|}
\hline & Sample Mean & $\begin{array}{l}\text { Standard } \\
\text { Deviation }\end{array}$ & Method of Analysis \\
\hline Bulk Density & $1.35 \mathrm{~g} / \mathrm{cm}^{3}$ & $0.03 \mathrm{~g} / \mathrm{cm}^{3}$ & Core method \\
\hline Soil texture & Silt loam & & USDA textural triangle \\
\hline Sand & $19.5 \%$ & $1.9 \%$ & Modified pipet \\
\hline Silt & $56.8 \%$ & $3.0 \%$ & \\
\hline Clay & $23.6 \%$ & $1.3 \%$ & \\
\hline Organic Matter & $11.5 \%{ }^{b}$ & $0.5 \%$ & Loss on Ignition \\
\hline $\mathrm{pH}$ & 6.7 & 0.2 & Soil:water::1:1 \\
\hline Total N & $0.23 \%^{[\mathrm{b}]}$ & $0.02 \%$ & Combustion \\
\hline $\mathrm{NH}_{4}{ }^{+}-\mathrm{N}$ & $8.8 \mathrm{mg} / \mathrm{kg}^{[\mathrm{b}]}$ & $1.0 \mathrm{mg} / \mathrm{kg}$ & Titration \\
\hline $\mathrm{NO}_{3}^{-}-\mathrm{N}$ & $20.5 \mathrm{mg} / \mathrm{kg}^{[\mathrm{b}]}$ & $4.3 \mathrm{mg} / \mathrm{kg}$ & Specific ion electrode \\
\hline $\mathrm{TP}$ & $67.0 \mathrm{mg} / \mathrm{kg}^{[\mathrm{b}]}$ & $49.0 \mathrm{mg} / \mathrm{kg}$ & Mehlich 3 extractant \\
\hline CEC & $13.4 \mathrm{meq} / 100 \mathrm{~g}^{[\mathrm{b}]}$ & $1.6 \mathrm{meq} / 100 \mathrm{~g}$ & Summation of cations \\
\hline
\end{tabular}

${ }^{[\mathrm{a}]}$ Means based on three samples

${ }^{[b]}$ Oven-dry basis

\subsection{Treatment Design}

There were four treatments: control, broadcast, surface-banded, and incorporated band. The control treatment was added to evaluate runoff water quality and ammonia volatilization in the absence of turkey litter application. Except for the control treatment, all other treatments received turkey litter at a rate of $4500 \mathrm{~kg} / \mathrm{ha}$ (approx. 2 tons $/ \mathrm{ac}$ ) for both the runoff as well as ammonia volatilization studies. Each treatment was replicated three times in both studies. 


\subsection{Statistical Methods}

For the same runoff or sampling event, pollutant loadings, in $\mathrm{kg} / \mathrm{ha}$ or $\mathrm{g} / \mathrm{ha}$ were compared among treatments using Analysis of Variance (ANOVA) (Keppel, 1982) with a level of significance of $5 \%(\alpha=0.05)$. For unbalanced data sets General Linear Model (GLM) was used (Keppel, 1982). Fisher's Least Significant Difference (LSD) (Keppel, 1982) was used to make pairwise comparisons $(\alpha=0.05)$. Pair-wise comparisons were made only if the ANOVA p-value was less than $\alpha$. Statistical Package for the Social Sciences (SPSS) as well as SAS were used for the analysis of data. No statistical analyses were made to compare pollutant concentrations between runoff or sampling events.

\subsection{Turkey Litter Characteristics}

Dry turkey litter from a plastic covered stack was obtained and stored in sealed containers until time of application. The turkey litter was sieved through $1.3 \mathrm{~cm}(1 / 2 \mathrm{in}$.) wire mesh before application to remove the large chunks of turkey litter that could have affected uniformity of application. The sieved turkey litter was analyzed for selected physical and chemical properties (see Table 3.2.).

Table 3.2. Physical and Chemical Properties of the Turkey Litter ${ }^{[\mathrm{a}]}$

\begin{tabular}{llll}
\hline & Sample Mean & Standard Deviation & Method of Analysis \\
\hline Moisture Content & $289.7 \mathrm{~g} / \mathrm{kg}$ & $5.2 \mathrm{~g} / \mathrm{kg}$ & Oven drying \\
$\mathrm{TKN}$ & $26.6 \mathrm{~g} / \mathrm{kg}$ & $2.8 \mathrm{~g} / \mathrm{kg}$ & Titration \\
$\mathrm{Ammoniacal}-\mathrm{N}$ & $6.3 \mathrm{~g} / \mathrm{kg}$ & $0.0 \mathrm{~g} / \mathrm{kg}$ & Titration \\
$\mathrm{TP}$ & $9.6 \mathrm{~g} / \mathrm{kg}$ & $0.0 \mathrm{~g} / \mathrm{kg}$ & Mehlich 3 extractant \\
$\mathrm{C}: \mathrm{N}$ & 11.3 & 1.3 & Calculated \\
$\mathrm{K}$ & $18.8 \mathrm{~g} / \mathrm{kg}$ & $0.7 \mathrm{~g} / \mathrm{kg}$ & Mehlich 3 extractant \\
$\mathrm{pH}$ & 8.5 & 0.0 & Electrode $(1: 2)$ \\
\hline
\end{tabular}

[a] Sample means were based on two samples.

${ }^{[\mathrm{b}]}$ Wet basis 


\subsection{Field Layout}

Treatments were randomly assigned to the plots. As shown in figure 3.1, runoff plots were paired for the convenience for applying simulated rainfall to two plots simultaneously. At three replications per treatment, including control treatment, there were 12 plots. Ammonia samplers were placed $>600 \mathrm{~cm}$ uphill of the runoff plots to minimize cross-contamination, as shown in figure 3.1. While two ammonia samplers were installed in each replication of the control, broadcast, surface-banded, and incorporated band treatment, the reference treatment using ammonium hydroxide had only one sampler (discussed later). Runoff and ammonia volatilization studies are discussed below separately.

\subsection{Runoff Study}

\subsubsection{Field Operations}

Each runoff plot measured $1 \mathrm{~m} \mathrm{X} 2 \mathrm{~m}$ and was hydrologically isolated using galvanized sheet metal borders. A steel collection trough was installed at the downstream end of each plot for runoff collection and was sealed with bentonite to prevent leakage. A collection pit was dug using a backhoe for each pair of plots. Each collection system was connected to a 68 -L container using a flexible pipe. The containers were covered to prevent contamination.

The treatments were applied in a single dose to plots that had very little residue cover, except for the 9-cm tall wheat stalk. This practice followed the traditional practice of applying poultry litter in a single dose to fields prior to corn planting. In the broadcast treatments, $900 \mathrm{~g}$ of turkey litter were applied uniformly by hand to obtain an application rate of $4500 \mathrm{~kg} / \mathrm{ha}$. In the surface banded treatment, turkey litter bands were formed using a 10.2-cm (4-in.) wide, 1-m long piece of PVC pipe. The PVC pipe was cut in half to form a $10.2 \mathrm{~cm}(4$ in.) trough and its 


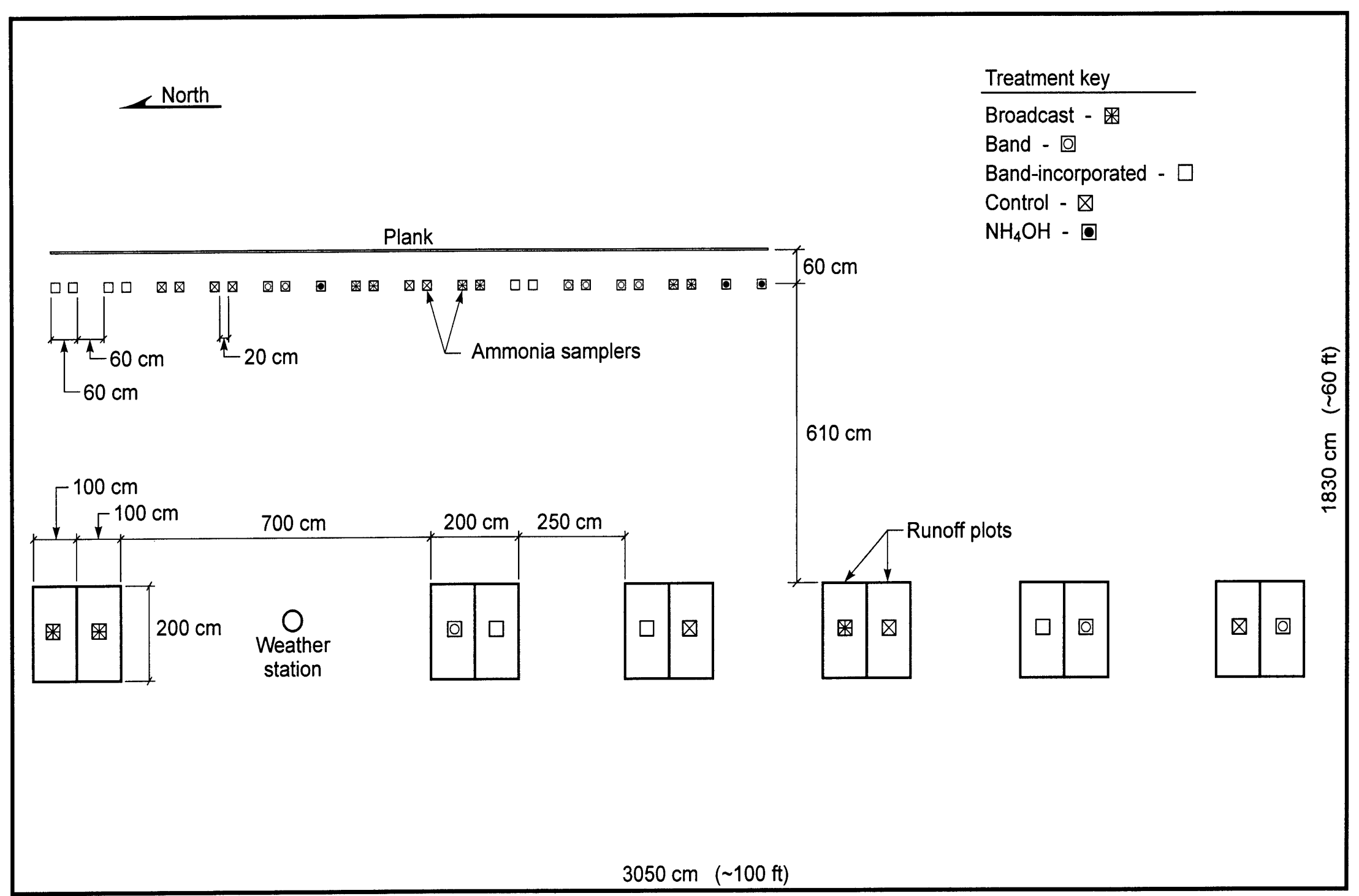

Figure 3.1. Layout of the field site 
ends were capped. Turkey litter (300 g) was poured into the trough, shaken lightly to evenly distribute the litter, and poured over the designated areas within the plot to form a $10.2-15.2 \mathrm{~cm}$ (4-6 in.) band. Three turkey litter bands were applied to each banded plot for a total of $900 \mathrm{~g}$ of litter to obtain an application rate of $4500 \mathrm{~kg} / \mathrm{ha}$. Each band was uniformly compacted using the flat side of a spade to replicate the action of a compaction wheel. In the incorporated band treatment turkey litter was applied using the same technique as the banded application; however, the bands were incorporated using a fork to a depth of $\sim 9 \mathrm{~cm}(3.5 \mathrm{in}$.$) to replicate the action of a$ rotary hoe. After incorporation, the flat side of a spade was used to compact the incorporated bands.

A weather station consisting of a tipping bucket rain gauge and thermometer was installed at the field site (figure 3.1). The weather station was connected to a data logger that recorded rainfall and temperature every hour.

\subsubsection{Rainfall Simulation}

Rainfall simulation was conducted using a rainfall simulator described by Shelton, von Bernuth, and Rajbhandari (1985). In addition to being portable, this rainfall simulator is widely used for the USDA-ARS P runoff study being conducted nationwide. The area inside the simulator measures $3 \mathrm{~m} \mathrm{X} 3 \mathrm{~m}$ and utilizes a single spray nozzle (30WSQ); the rainfall simulator uniformity coefficient is $93 \%$. Canvas covers on the sides of the simulator eliminate wind effects. At $27.6 \mathrm{kPa}$ (4 psi), the simulator applies rainfall at $7.5 \mathrm{~cm} / \mathrm{hr}$. Water is supplied to the simulator using a stationary tank and pressurized using a gasoline water pump. A pressure regulator is used to maintain desired pressure and a flow meter is used to monitor volume of water applied. 


\subsubsection{Runoff Collection}

Covered collection tubs were left in place to collect runoff from natural rainfall events (see Figure 3.2.). The first rainfall event produced $2.2 \mathrm{~cm}$ on day 2, one day after turkey litter application. Since the weather station was not installed at the time when the first natural rainfall event occurred, rainfall amount was obtained from the National Weather Service's weather station at the Hart Municipal Airport $\sim 2 \mathrm{~km}$ from the field site. Runoff samples from the first natural runoff event could not be collected because collection tub covers were blown away and samples were contaminated with rainwater. Runoff resulting from the second natural rainfall event of $0.8 \mathrm{~cm}$ occurring on day 3 was collected. The volume of runoff collected was recorded and a sample was obtained from each plot. The runoff samples were kept on ice until delivery to the laboratory for analysis. Samples not analyzed immediately were stored at $4^{\circ} \mathrm{C}$. Due to heavy rainfall and flooding of the collection pits, on June 6, 2002, the plots were covered with plastic. The plastic cover was removed when rainfall stopped.

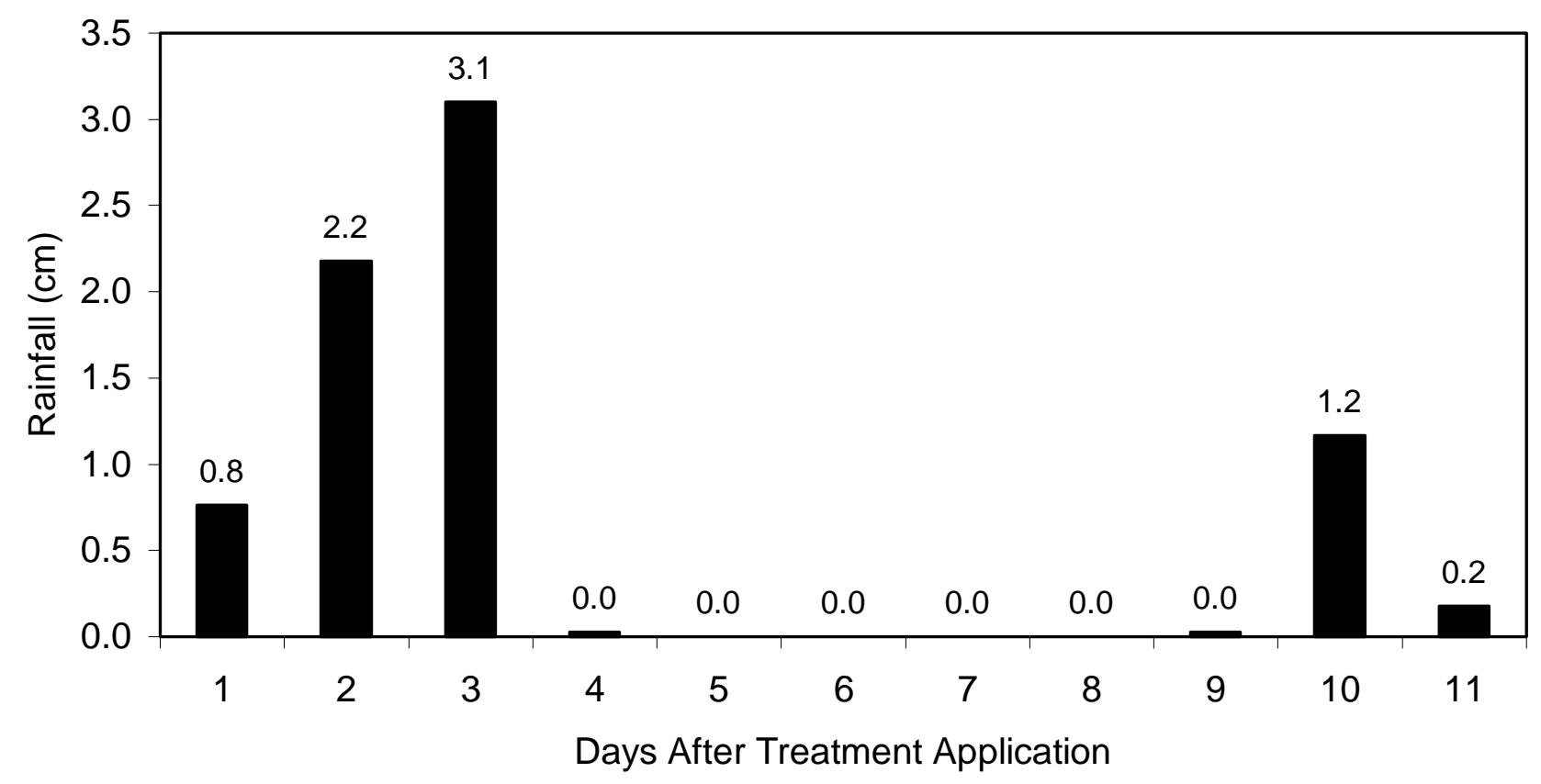

Figure 3.2. Natural rainfall during the runoff study 
Rainfall simulation was applied to plots 2 and $7 \mathrm{~d}$ after application of treatments. Rainfall was applied at a rate of $7.5 \mathrm{~cm} / \mathrm{hr}$ until runoff started as a steady stream through the collection tubes after which rainfall was applied for 30 minutes. Thereafter, rainfall was terminated and collection of runoff continued until water flow from the plot ceased. Rain gauges were installed in the plots to measure simulated rainfall. Samples of simulated runoff were collected using procedures identical to the procedure used for collecting runoff from natural rainfall.

\subsubsection{Analysis of Runoff Constituents}

Analysis of runoff constituents was conducted at the WVU Natural Resource Center for Coal and Energy Laboratory, Morgantown, WV. The constituents analyzed are listed in Table 3.3 .

Table 3.3. Analytical Methods Used in Testing Runoff Constituents

\begin{tabular}{ll}
\hline Constituent & Method of Analysis \\
\hline $\mathrm{NO}_{3}^{-}-\mathrm{N}$ & Colorimetric, filtered \\
$\mathrm{Ammoniacal}-\mathrm{N}$ & Distillation and titration \\
TKN & Digestion, distillation and titration \\
Total P & Atomic emission, ICP \\
SBRP & Colorimetric, filtered \& unfiltered \\
DRP & Colorimetric, filtered and unfiltered \\
TSS & Gravimetric \\
\hline
\end{tabular}




\subsection{Ammonia Volatilization Study}

\subsubsection{Ammonia Sampler Design and Fabrication}

Ammonia volatilization was measured using passive ammonia samplers (see Figure 3.3.) that utilized a filter paper impregnated with citric acid $\left(\mathrm{C}_{6} \mathrm{H}_{8} \mathrm{O}_{7}\right)$. Citric acid was used for this study because of its high efficiency in trapping $\mathrm{NH}_{3}$ and also because it is safer to use than phosphoric acid and sulfuric acid (Rebaud, James, Ashbaugh, and Flocchini, 2001). A 0.5 M solution of citric acid was prepared by dissolving $211.34 \mathrm{~g}$ of citric acid granules in a mixture of 0.11 L deionized, distilled water and 2.09 $\mathrm{L}$ of ethanol. Glass fiber filter papers measuring 10 $\mathrm{cm}$ X $20 \mathrm{~cm}$ were soaked for 2 minutes in the citric acid solution, dried and stored separately in plastic bags. Rebaud et al. (2001) used citric acid at a concentration of $0.16 \mathrm{M}$ for ammonia sampling. Compared to Rebaud et al. (2001), since greater ammonia loadings were expected in this study, a $0.5 \mathrm{M}$ citric acid solution was used.
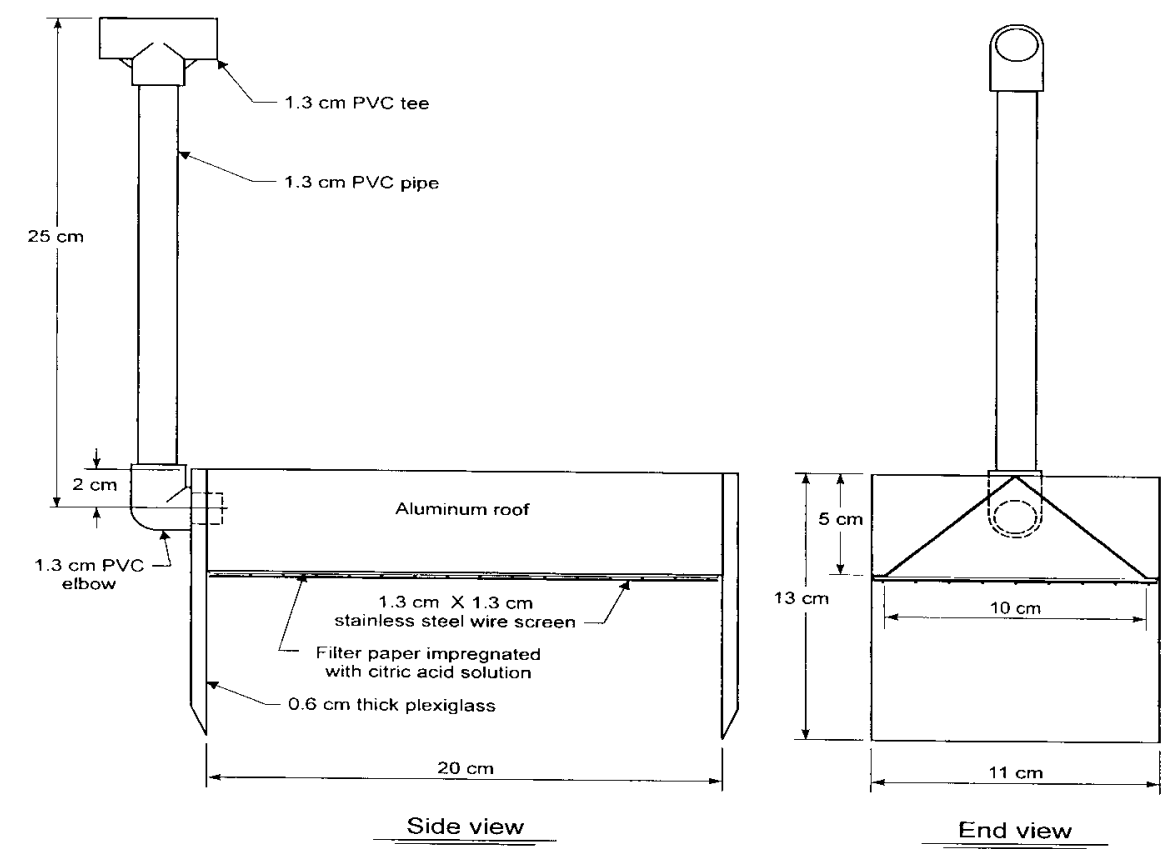

Figure 3.3. Ammonia sampler design 
The ammonia sampler covered an area of $200 \mathrm{~cm}^{2}(20 \mathrm{~cm} \times 10 \mathrm{~cm})$. Solar radiation on the aluminum roof of the sampler created natural convection causing $\mathrm{NH}_{3}$ in the turkey litter to rise upwards, allowing it to react with the citric acid in the filter paper. The $\mathrm{NH}_{3}$ sampler design used in this study was intended to capture ammonia volatilization occurring due to natural convection and molecular diffusion, but not forced convection (i.e., wind). The citric acidimpregnated filter paper was located $3 \mathrm{~cm}$ above the bare soil surface or soil surface that received turkey litter application.

Since micro-plots were used in this study, micro-meteorological methods, such as those used by Marshal et al., (1998) could not be used because of possible cross-contamination between treatments. Totally isolated samplers such as those used by Nathan and Malzer (1994) and Nommik (1973) would have created environmental conditions in the sampling area that would have greatly differed from normal environmental conditions, especially, air movement and temperature. Samplers using recirculating fans such as that used by Black, Sherlock, Cameron, Smith, and Goh (1985) were not used because of the high expense of sampling apparatus and the drastic difference in environmental conditions in the sampler compared with ambient conditions. Hence, the sampler design was considered suitable for this study.

\subsubsection{Sampler Efficiency Evaluation}

The ammonia trapping efficiency of the ammonia sampler was tested using reference samplers containing ammonium hydroxide $\left(\mathrm{NH}_{4} \mathrm{OH}\right)$. Depending on the duration of sampling, $20-30 \mathrm{~mL}$ of $\mathrm{NH}_{4} \mathrm{OH}$ was placed in a petri dish under the sampler at sampling time. The same volume of $\mathrm{NH}_{4} \mathrm{OH}$ was also transferred to a $\mathrm{HDPE}$ bottle containing $5 \mathrm{~mL}$ of concentrated sulfuric acid $\left(\mathrm{H}_{2} \mathrm{SO}_{4}\right)$. At the end of the sampling period, the $\mathrm{NH}_{4} \mathrm{OH}$ remaining in the petri dish 
was transferred to a HDPE bottle containing $5 \mathrm{~mL}$ of concentrated $\mathrm{H}_{2} \mathrm{SO}_{4}$ and taken to the laboratory for analysis. Filter paper from the reference sampler was transferred to a HDPE bottle containing $200 \mathrm{~mL}$ of $2 \mathrm{M}$ potassium chloride $(\mathrm{KCl})$ and $5 \mathrm{~mL}$ of concentrated $\mathrm{H}_{2} \mathrm{SO}_{4}$.

Efficiency of the ammonia sampler was calculated using the following equation.

$$
\eta_{N H_{3}}=\frac{\left[\mathrm{NH}_{3}\right]_{f p} \times 100}{\left[N H_{3}\right]_{i n_{-} p d}-\left[\mathrm{NH}_{3}\right]_{f n_{-} p d}}
$$

where: $\eta_{\mathrm{NH}_{3}}=$ efficiency of $\mathrm{NH}_{3}$ sampler, (\%),

$\left[\mathrm{NH}_{3}\right]_{\mathrm{fp}}=\mathrm{NH}_{3}$ concentration in filter paper $(\mathrm{mg})$,

$\left[\mathrm{NH}_{3}\right]_{i n_{\text {_pd }}}=$ initial $\mathrm{NH}_{3}$ concentration in filter paper $(\mathrm{mg})$, and

$\left[\mathrm{NH}_{3}\right]_{\text {fin_pd }}=$ final $\mathrm{NH}_{3}$ concentration in filter paper $(\mathrm{mg})$

\subsubsection{Field Operations}

The ammonia samplers were located $>600 \mathrm{~cm}(\sim 20 \mathrm{feet})$ uphill and parallel to the runoff plots (see Figure 3.1.). Planks were installed upslope of the ammonia samplers to prevent run-on from the uphill areas. In addition to control, broadcast, banded, and incorporated band treatments, a reference treatment using ammonium hydroxide $\left(\mathrm{NH}_{4} \mathrm{OH}\right)$ (discussed earlier) was used in the study to determine $\mathrm{NH}_{3}$ trapping efficiency of the sampler. Treatments were assigned to the micro-plots through randomization at three replications per treatment. Except for the reference treatment, which had one sampler per replication, the other treatments had two samplers per replications to reduce variability.

Turkey litter was applied to the treatments using procedures described in the runoff study. Based on the area of the sampler $\left(200 \mathrm{~cm}^{2}\right), 9 \mathrm{~g}$ of turkey litter was applied in the broadcast treatment while $60 \mathrm{~g}$ was applied to the band or incorporated band treatments to obtain an application rate of $4500 \mathrm{~kg} / \mathrm{ha}$. A template was used to ensure that all of the applied turkey 
litter stayed beneath the sampler. Ammonia volatilization was sampled 6 h, 18 h, $3 \mathrm{~d}, 5 \mathrm{~d}, 7 \mathrm{~d}$, $9 \mathrm{~d}$, and $11 \mathrm{~d}$ after treatment was applied.

Ammonia samples were collected in $250 \mathrm{~mL}$ HDPE bottles. Each bottle contained 200 $\mathrm{mL}$ of $2 \mathrm{M} \mathrm{KCl}$ and $5 \mathrm{~mL}$ of concentrated $\mathrm{H}_{2} \mathrm{SO}_{4}$; the sample was acidified to minimize $\mathrm{NH}_{3}$ losses during tranport and storage. The bottles were transported to the laboratory on ice. Both

filter papers from a replication (only one in the case of reference treatment) were transferred into a single collection bottle for analysis.

Since $\mathrm{NH}_{3}$ volatilization increases with temperature, the heating impact of the $\mathrm{NH}_{3}$ sampler roof was evaluated by measuring temperatures on the soil surface under the ammonia samplers and on the soil surface that was exposed to sunlight (outside the sampler).

Temperatures were taken with K-type thermocouples, and recorded by a data logger at 5-minute intervals for four hours.

\subsubsection{Sample Analysis}

The samples were frozen prior to analysis and were analyzed using a Kjeltech 1030 autoanalyzer. Addition of excess sodium hydroxide to an aliquot of the sample resulted in release of ammonia in gaseous form, which was then distilled in a saturated solution of boric acid. The boric acid-ammonia complex was titrated with a known volume of $0.1 \mathrm{M} \mathrm{HCl}$ to determine ammonia concentration in the sample solution. Based on the total volume of solution and ammonia concentration in the solution, ammonia-N volatilization ( $\mathrm{g} / \mathrm{ha}$ ) was determined. 


\section{Chapter 4}

\section{Results and Discussion}

Objective I was achieved by conducting a runoff study utilizing different turkey litter application methods. In addition to runoff volume, runoff water quality was also considered. Objective II was achieved with the use of ammonia samplers.

\subsection{Water Quality Study}

Objective I: Evaluate the effects of different turkey litter application methods on total runoff volume as well as nitrate- $\mathrm{N}\left(\mathrm{NO}_{3}{ }^{-}-\mathrm{N}\right)$, ammoniacal- $\mathrm{N}\left(\mathrm{NH}_{4}{ }^{+}-\mathrm{N}+\mathrm{NH}_{3}-\mathrm{N}\right)$, total Kjeldahl $\mathrm{N}$ (TKN), total P (TP), dissolved reactive $\mathrm{P}$ (DRP), sediment bound reactive $\mathrm{P}$ (SBRP), and total suspended solids (TSS) concentrations in surface runoff.

\subsubsection{Runoff Volume}

Treatment impact on runoff volume is presented in Table 4.1. Analysis of Variance (ANOVA) indicated that there was no significant difference in runoff volume $(\alpha=0.05)$ among treatments in any of the runoff events. The statistical outputs are presented in Appendix B.

Given that all plots were partially bare due to removal of baled hay, lower runoff (due to greater infiltration) had been expected in incorporated band treatment than the other treatments

for the first event (natural runoff). However, high within-treatment variability (as indicated by high standard deviation values) (see Table 4.1.) could have resulted in lack of significant difference among treatments in all events. For the remaining runoff events, surface sealing due to raindrop impact likely neutralized the impact of tillage in the incorporated band treatment versus the other treatments. 
Table 4.1. Treatment Effect on Runoff Volume: Results of the Statistical Analysis at $\alpha=0.05^{[a]}$

\begin{tabular}{|c|c|c|c|c|c|c|}
\hline \multirow{3}{*}{ Treatment } & \multicolumn{6}{|c|}{ Runoff Volume $\left(\mathrm{m}^{3} / \mathrm{ha}\right)$} \\
\hline & \multicolumn{2}{|c|}{ Natural Runoff } & \multicolumn{2}{|c|}{$\begin{array}{l}\text { Simulated Runoff } \\
\text { Event } 1\end{array}$} & \multicolumn{2}{|c|}{$\begin{array}{l}\text { Simulated Runoff } \\
\text { Event } 2\end{array}$} \\
\hline & Mean & $\begin{array}{r}\text { Standard } \\
\text { Deviation }\end{array}$ & Mean & $\begin{array}{r}\text { Standard } \\
\text { Deviation }\end{array}$ & Mean & $\begin{array}{r}\text { Standard } \\
\text { Deviation }\end{array}$ \\
\hline Broadcast & 9.5 & 6.0 & 130.9 & 37.0 & 52.6 & 39.8 \\
\hline Band & 8.8 & 6.4 & 103.4 & 32.8 & 65.2 & 47.2 \\
\hline Incorporated band & 3.5 & 1.4 & 86.1 & 59.5 & 71.0 & 45.7 \\
\hline Control & 14.8 & 12.6 & 161.5 & 18.5 & 117.1 & 64.0 \\
\hline F-value & & 1.10 & & 44 & & \\
\hline p-value & & .40 & & 30 & & \\
\hline
\end{tabular}

${ }^{[\mathrm{a}]}$ Mean of three replications.

\subsubsection{Nitrate-Nitrogen}

Treatment impact on $\mathrm{NO}_{3}{ }^{-} \mathrm{N}$ loading is presented in Table 4.2. While ANOVA was used to evaluate the natural runoff and simulated event 2 , simulated event 1 was evaluated using the general linear model (GLM) due to the presence of unbalanced data sets. Nitrate nitrogen concentrations are presented in Appendix A. The statistical outputs are presented in Appendix B.

At $\alpha=0.05$, there were no significant difference among treatments in any of the events (see Table 4.2). Since turkey litter is low in $\mathrm{NO}_{3}{ }^{-} \mathrm{N}$ concentrations (Collins, Barker, Carr, Brodie, and Martin, 1999) little or no difference in $\mathrm{NO}_{3}{ }^{-} \mathrm{N}$ loadings among the treatments had been expected. Again, high within treatment variability (as indicated by high standard deviation values) could have resulted in lack of significant difference among treatments. 
Table 4.2. Treatment Effect on $\mathrm{NO}_{3}^{-}-\mathrm{N}$ : Results of the Statistical Analysis at $\alpha=0.05^{[a]}$

$$
\mathrm{NO}_{3}^{-}-\mathrm{N}(\mathrm{g} / \mathrm{ha})
$$

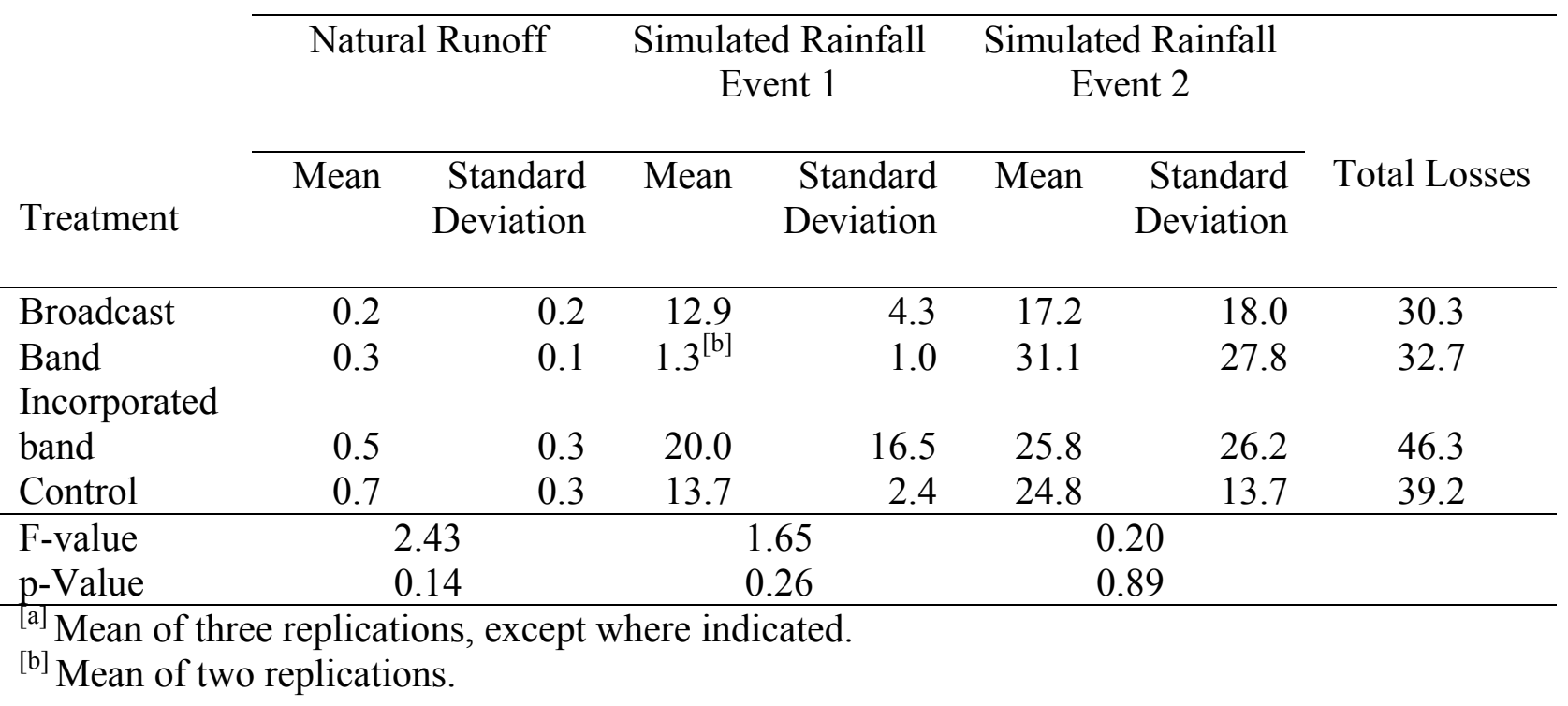

Lower $\mathrm{NO}_{3}{ }^{-}$loading during the natural rainfall could have been due to the smaller depth of rainfall $(0.8 \mathrm{~cm})$ compared with $6.4 \mathrm{~cm}$ at $7.5 \mathrm{~cm} / \mathrm{h}$ in averaged over all treatments, in simulated rainfall event 1 . Based on the mean data, compared with simulated runoff event one, higher $\mathrm{NO}_{3}{ }^{-}-\mathrm{N}$ losses in simulated runoff event two could be attributed to greater availability of $\mathrm{NO}_{3}{ }^{-}-\mathrm{N}$ for loss in runoff due to conversion of organic-N and $\mathrm{NH}_{4}{ }^{+}-\mathrm{N}$ into $\mathrm{NO}_{3}{ }^{-}-\mathrm{N}$ during the intervening period (7 days). Overall, $\mathrm{NO}_{3}{ }^{-}-\mathrm{N}$ loadings were low for all treatments.

\subsubsection{Ammoniacal-Nitrogen}

Treatment impact on $\mathrm{NH}_{4}{ }^{+}-\mathrm{N}$ losses was tested in each of the runoff events. Natural runoff and simulated runoff event two were calculated using ANOVA. Because of unbalanced data sets in simulated runoff event one, GLM was used. Means, standard deviations, and 
p-values are presented in Table 4.3. Ammoniacal-N concentrations are presented in Appendix

A. The statistical outputs are presented in Appendix B.

Table 4.3. Treatment Effect on Ammoniacal - N: Results of the Statistical Analysis at $\alpha=0.05^{[a]}$

Ammoniacal N (g/ha)

$\begin{array}{ccc}\text { Natural Rainfall } & \begin{array}{c}\text { Simulated Rainfall } \\ \text { Event } 1\end{array} & \text { Simulated Rainfall } \\ \text { Event } 2\end{array}$

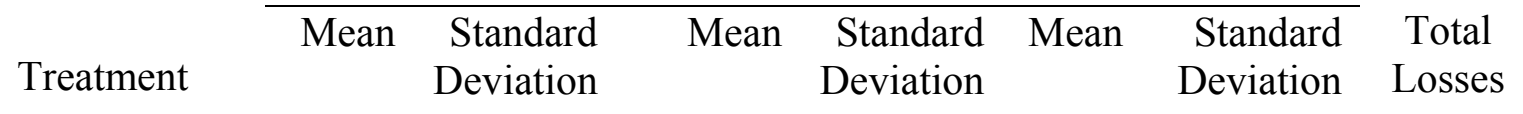

\begin{tabular}{lcccrrrr}
\hline Broadcast & 23.1 & 17.1 & 148.3 & 75.4 & 5.2 & 2.8 & 176.6 \\
Band & 20.2 & 17.1 & $249.1^{[\mathrm{b}]}$ & 187.2 & 9.6 & 10.3 & 278.9 \\
Incorporated & & & & & & & \\
band & 0.6 & 0.5 & 52.2 & 55.1 & 5.1 & 5.4 & 57.9 \\
Control & 1.9 & 2.2 & 10.8 & 8.00 & 5.1 & 3.3 & 17.8 \\
\hline F-value & 2.87 & & 3.64 & & 0.39 & & \\
p-Value & 0.10 & & 0.26 & & 0.76 & & \\
\hline
\end{tabular}

${ }^{[\mathrm{a}]}$ Mean of three replications, except where indicated.

${ }^{[b]}$ Mean of two replications.

At $\alpha=0.05$, there was no significant difference among treatments in any of the events (see Table 4.3). High within treatment variability (as indicated by high standard deviation values) could have resulted in lack of significant difference among treatments.

Incorporated band application had been expected to result in significantly lower levels of ammoniacal-N loading (due to reduced availability on the soil surface) than the other turkey litter application treatments. Compared with band application, incorporation of turkey litter could be expected to result in greater soil to litter contact, thus allowing soil microbes to convert ammoniacal $\mathrm{N}$ to $\mathrm{NO}_{3}{ }^{-}-\mathrm{N}$ more rapidly. Based on the means data, compared to simulated runoff event one, lower ammoniacal-N losses in the second simulated event could be attributed to 
nitrification, movement of $\mathrm{NH}_{4}{ }^{+}-\mathrm{N}$ into the soil, as well as ammoniacal-N depletion by runoff from the earlier rainfall events.

\subsubsection{Total Kjeldahl Nitrogen}

Treatment impact on TKN loading is presented in table 4.2. While ANOVA was used to evaluate the natural runoff and simulated event 2 , simulated event 1 was evaluated using the general linear model (GLM) due to the presence of unbalanced data sets. Total Kjeldahl N concentrations are presented in Appendix A. Statistical outputs are presented in Appendix B.

Table 4.4. Treatment Effect on TKN: Results of the Statistical Analysis at $\alpha=0.05^{[a]}$

TKN (g/ha)

\begin{tabular}{|c|c|c|c|c|c|c|c|}
\hline \multirow[b]{2}{*}{ Treatment } & \multicolumn{2}{|c|}{ Natural Runoff } & \multicolumn{2}{|c|}{$\begin{array}{l}\text { Simulated Runoff } \\
\text { Event } 1\end{array}$} & \multicolumn{2}{|c|}{$\begin{array}{l}\text { Simulated Runoff } \\
\text { Event } 2\end{array}$} & \multirow[b]{2}{*}{$\begin{array}{c}\text { Total } \\
\text { Losses }\end{array}$} \\
\hline & Mean & $\begin{array}{l}\text { Standard } \\
\text { Deviation }\end{array}$ & Mean & $\begin{array}{l}\text { Standard } \\
\text { Deviation }\end{array}$ & Mean & $\begin{array}{l}\text { Standard } \\
\text { Deviation }\end{array}$ & \\
\hline Broadcast & 1039.2 & 1103.7 & 1215.8 & 391.0 & 494.3 & 472.5 & 2749.3 \\
\hline $\begin{array}{l}\text { Band } \\
\text { Incorporated }\end{array}$ & 698.8 & 478.7 & $1502.1^{[b]}$ & 1045.0 & 478.1 & 242.1 & 2679.0 \\
\hline band & 247.1 & 125.4 & 1522.2 & 1206.6 & 773.7 & 642.6 & 2543.2 \\
\hline Control & 1011.0 & 797.5 & 1491.4 & 35.1 & 591.5 & 48.3 & 3093.9 \\
\hline F-value & & .78 & & 10 & & .32 & \\
\hline p-value & & .54 & & 96 & & .81 & \\
\hline
\end{tabular}

${ }^{[\mathrm{a}]}$ Mean of three replications, except where indicated.

${ }^{[b]}$ Mean of two replications.

At $\alpha=0.05$, there was no significant difference among treatments in any of the events (see Table 4.3.). It had been expected that incorporated band treatments would have resulted in lower TKN losses than the other turkey litter treatments due to reduced availability on the 
surface for transport in runoff. Again, high within treatment variability (as indicated by high standard deviation values) could have resulted in lack of significant difference among treatments.

Based on the means data, TKN loadings in runoff were generally greater in simulated runoff event one than in the second simulated event probably due to depletion of TKN in the earlier runoff events as well as conversion of organic $\mathrm{N}$ to $\mathrm{NO}_{3}{ }^{-}-\mathrm{N}$ through mineralization.

Based on TKN (see Table 4.4) and ammoniacal - N (see Table 4.2) loadings, organic N loadings were higher than inorganic $\mathrm{N}$ loadings in all treatments and events.

\subsubsection{Dissolved Reactive Phosphorus}

Treatment effect on DRP is presented in Table 4.4. Natural runoff and simulated runoff event two were analyzed using ANOVA. Because of unbalanced data sets in simulated runoff event one, GLM was used for calculations. Dissolved reactive P concentrations data is presented in Appendix A. Statistical outputs are presented in Appendix B.

Table 4.5. Treatment Effect on DRP: Results of the Statistical Analysis at $\alpha=0.05^{[a]}$

$$
\operatorname{DRP}(\mathrm{g} / \mathrm{ha})
$$

\begin{tabular}{ccc} 
Natural Runoff & $\begin{array}{c}\text { Simulated Runoff } \\
\text { Event 1 }\end{array}$ & $\begin{array}{c}\text { Simulated Runoff } \\
\text { Event 2 }\end{array}$ \\
\hline
\end{tabular}

\begin{tabular}{|c|c|c|c|c|c|c|c|}
\hline Treatment & Mean & $\begin{array}{l}\text { Standard } \\
\text { Deviation }\end{array}$ & Mean & $\begin{array}{l}\text { Standard } \\
\text { Deviation }\end{array}$ & Mean & $\begin{array}{l}\text { Standard } \\
\text { Deviation }\end{array}$ & Total Losses \\
\hline Broadcast & 4.0 & 4.3 & 258.3 & 158.9 & 20.7 & 15.3 & 283.0 \\
\hline $\begin{array}{l}\text { Band } \\
\text { Incorporated }\end{array}$ & 7.2 & 5.6 & $442.8^{[b]}$ & 330.3 & 47.8 & 36.8 & 497.8 \\
\hline band & 1.2 & 0.7 & 53.7 & 46.5 & 21.3 & 15.9 & 76.2 \\
\hline Control & 4.0 & 3.0 & 50.6 & 13.1 & 25.3 & 16.1 & 156.1 \\
\hline F-value & & 1.21 & & 61 & & 0.94 & \\
\hline$p$-value & & 0.37 & & .26 & & 0.46 & \\
\hline
\end{tabular}

${ }^{[\mathrm{a}]}$ Mean of three replications, except where indicated.

${ }^{[b]}$ Mean of two replications. 
At $\alpha=0.05$, there was no significant difference among treatments in any of the events (seeTable 4.5). Compared with other treatments, DRP losses were expected to be lower in incorporated bands because little of the $\mathrm{P}$ in litter would be available on the soil surface for transport in runoff. Again, high within treatment variability (as indicated by high standard deviation values) could have resulted in lack of significant difference among treatments.

Based on mean values, DRP losses were much higher in simulated runoff event one than the other events. The natural rainfall event $(0.8 \mathrm{~cm})$ produced low volume of runoff that resulted in lower DRP loadings, compared with the simulated runoff events. Since DRP is not only removed in runoff, but also in percolating water (resulting in conversion of some DRP to SBRP), simulated runoff event two resulted in lower DRP loading than in the earlier events due to DRP removal by the previous runoff events.

\subsubsection{Sediment Bound Reactive Phosphorus}

Treatment impact on SBRP loading is presented in Table 4.6. While ANOVA was used to evaluate the natural runoff and simulated event 2 , simulated event 1 was evaluated using GLM, due to the presence of unbalanced data sets. Sediment bound reactive P concentrations are presented in Appendix A. Statistical outputs are presented in Appendix B.

At $\alpha=0.05$, there was no significant difference among treatments in any of the events (see Table 4.6). Again, high within treatment variability (as indicated by high standard deviation values) could have resulted in lack of significant difference among treatments. Higher losses were experienced in simulated runoff event one compared with the other events. Natural rainfall produced lower runoff volume and hence, lower SBRP loadings compared with the simulated events. Natural runoff event and the first simulated runoff event likely removed most of the 
SBRP in the runoff, thus resulting in lower loadings in simulated event two. Dissolved reactive P loadings were higher than SBRP probably due to wet, and hence, anaerobic conditions on the plots that likely increased conversion of SBRP to DRP. Because DRP is in solution it is easier to transport than SBRP and could result in higher DRP loading.

Table 4.6. Treatment Effect on SBRP: Results of the Statistical Analysis at $\alpha=0.05^{[a]}$

$$
\text { SBRP (g/ha) }
$$

$\begin{array}{ccc}\text { Natural Runoff } & \text { Simulated Runoff } & \text { Simulated Runoff } \\ \text { Event } 1 & \text { Event } 2\end{array}$

\begin{tabular}{|c|c|c|c|c|c|c|c|}
\hline Treatment & Mean & $\begin{array}{r}\text { Standard } \\
\text { Deviation }\end{array}$ & Mean & $\begin{array}{r}\text { Standard } \\
\text { Deviation }\end{array}$ & Mean & $\begin{array}{r}\text { Standard } \\
\text { Deviation }\end{array}$ & $\begin{array}{c}\text { Total } \\
\text { Losses }\end{array}$ \\
\hline Broadcast & 10.6 & 8.2 & 1.5 & 2.6 & 0.9 & 1.0 & 13.0 \\
\hline Band & 4.7 & 3.8 & $130.3^{[\mathrm{b}]}$ & 151.8 & 2.3 & 2.5 & 137.3 \\
\hline $\begin{array}{l}\text { Incorporated } \\
\text { band }\end{array}$ & 0.5 & 0.3 & 20.3 & 32.4 & 1.0 & 0.9 & 21.8 \\
\hline Control & 0.9 & 0.6 & 2.6 & 0.7 & 2.1 & 1.6 & 5.6 \\
\hline $\begin{array}{l}\text { F-value } \\
\text { p-value }\end{array}$ & & $\begin{array}{l}0.08 \\
0.84\end{array}$ & & $\begin{array}{l}.33 \\
.16\end{array}$ & & $\begin{array}{l}0.61 \\
0.63\end{array}$ & \\
\hline
\end{tabular}

${ }^{\text {aa] }}$ Mean of three replications, except where indicated.

${ }^{[b]}$ Mean of two replications.

\subsubsection{Total Phosphorus}

Treatment impact TP loading is presented in Table 4.7. While ANOVA was used to evaluate the natural runoff and simulated event 2 , simulated event 1 was evaluated using GLM due to the presence of unbalanced data sets. Total $\mathrm{P}$ concentration data are presented in Appendix A. Statistical outputs are presented in Appendix B.

At $\alpha=0.05$, there was no significant difference among treatments in any of the events (see Table 4.7). It had been expected that total P loading in runoff would be lower in 
incorporated bands than other turkey litter treatments due to incorporation which would reduce $\mathrm{P}$ available for removal in runoff. Again, high within treatment variability (as indicated by high standard deviation values) could have resulted in lack of significant difference.

Table 4.7. Treatment Effect on TP: Results of the Statistical Analysis at $\alpha=0.05^{[a]}$

$\mathrm{TP}(\mathrm{g} / \mathrm{ha})$

\begin{tabular}{ccc}
\hline Natural Runoff & Simulated Runoff & Simulated Runoff \\
& Event 1 & Event 2
\end{tabular}

Mean Standard Mean Standard Mean Standard Total

Treatment Deviation Deviation Deviation Losses

\begin{tabular}{lrrrrrrr}
\hline Broadcast & 56.1 & 46.5 & 246.3 & 46.8 & 22.9 & 12.0 & 325.3 \\
Band & 36.7 & 27.7 & $717.0^{[\mathrm{b}]}$ & 732.1 & 47.5 & 24.3 & 801.2 \\
Incorporated & & & & & & & \\
band & 7.2 & 5.0 & 269.8 & 233.4 & 107.6 & 82.3 & 384.6 \\
Control & 16.8 & 7.7 & 213.6 & 141.0 & 140.9 & 104.4 & 371.3 \\
\hline F-value & 1.88 & & 1.26 & & 1.91 & & \\
p-value & 0.21 & & 0.07 & & 0.21 & & \\
\hline
\end{tabular}

${ }^{[a]}$ Mean of three replications, except where indicated.

${ }^{[b]}$ Mean of two replications.

Based on mean values, higher total P losses in all treatments in the first simulated event than the natural event was likely due to greater depth and intensity of rainfall resulting in more runoff and hence, greater removal of P. Again, based on mean loadings, lower total P concentrations in the second simulated event could have been due to mineralization of $\mathrm{P}$ into DRP and its movement into the soil as well as depletion of total P by runoff from the first simulated event. Based on mean values, inorganic $\mathrm{P}$ losses were generally higher than organic $\mathrm{P}$ losses based on SBRP (see Table 4.6.) loadings and DRP (see Table 4.5.) loadings. 


\subsubsection{Total Suspended Solids}

Treatment impact on TSS loading is presented in Table 4.8. While ANOVA was used to evaluate the natural runoff and simulated event 2 , simulated event 1 was evaluated using GLM due to the presence of unbalanced data sets. Total suspended solids concentrations are presented in Appendix A. Statistical outputs are presented in Appendix B.

Table 4.8. Treatment Effect on TSS: Results of the Statistical Analysis at $\alpha=0.05^{[a]}$

TSS (kg/ha)

$\begin{array}{ccc}\text { Natural Runoff } & \text { Simulated Runoff } & \text { Simulated Runoff } \\ \text { Event } 1 & \text { Event } 2\end{array}$

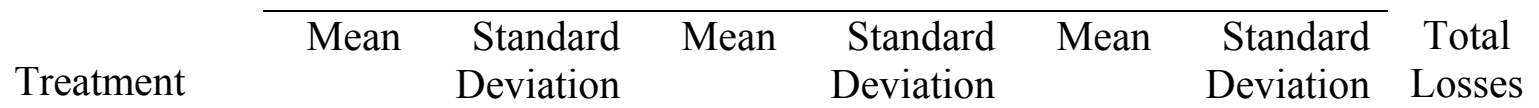

\begin{tabular}{|c|c|c|c|c|c|c|c|}
\hline Broadcast & 1.4 & 0.6 & 13.5 & 6.1 & 1.2 & 0.7 & 16.1 \\
\hline Band & 1.6 & 0.7 & $10.2^{[\mathrm{b}]}$ & 2.4 & 0.3 & 0.5 & 12.1 \\
\hline $\begin{array}{l}\text { Incorporated } \\
\text { band }\end{array}$ & 0.3 & 0.1 & 7.2 & 4.7 & 0.0 & 0.0 & 7.5 \\
\hline Control & 1.3 & 1.4 & 17.7 & 2.4 & 2.2 & 3.8 & 21.2 \\
\hline F-value & & & & & & & \\
\hline p-value & & & & & & & \\
\hline
\end{tabular}

${ }^{[\mathrm{a}]}$ Mean of three replications, except where indicated.

${ }^{[b]}$ Mean of two replications.

At $\alpha=0.05$, there were no significant difference among treatments in any of the events (table 4.8). High within treatment variability (as indicated by high standard deviation values) may have contributed to the lack of significant differences among treatments.

The natural rainfall produced low runoff volumes (see Table 4.1), thus contributing to low TSS loadings. Based on mean values, simulated runoff event one produced the highest SS loadings since runoff volumes were the highest in that event (see Table 4.1). 


\subsection{Ammonia Volatilization Study}

Objective II: Evaluate $\mathrm{NH}_{3}$ volatilization losses from the three turkey litter application methods.

The ammonia volatilization study was conducted for $11 \mathrm{~d}$, after application of treatments. The study involved seven sampling events, namely, 0-6 h (event 1), 6-24 h (event 2), 24-72 h (event 3), 72-120 h (event 4), 120-168 h (event 5), 168-216 h (event 6), and 216-264 h (event 7).

\subsubsection{Event One ( $0-6 \mathrm{~h}, 6 \mathrm{~h}$ duration)}

Treatment impact on $\mathrm{NH}_{3}$ volatilization during event 1 is given in Figure 4.1. The treatments were significantly different (ANOVA $p=<0.01 ; \alpha=0.05$ ). Statistical outputs are presented in Appendix B.

With pairwise comparison, band application produced significantly higher $\mathrm{NH}_{3}-\mathrm{N}$ volatilization losses ( $\mathrm{LSD}=40.5 \mathrm{~g} / \mathrm{ha}$ ) than the other treatments (see Figure 4.1). It had been expected that broadcast application would have resulted in the highest $\mathrm{NH}_{3}$ volatilization. Since broadcast application allowed for greater soil contact (due to thin residue cover), the lower soil $\mathrm{pH}$ (6.7) could have reduced the $\mathrm{pH}$ of turkey litter (8.5) resulting in little of the ammoniacal-N being in the $\mathrm{NH}_{3}-\mathrm{N}$ form. Also, greater soil-litter contact allowed for conversion of $\mathrm{NH}_{3}$ into the more stable $\mathrm{NH}_{4}{ }^{+}$form in the broadcast treatment compared to band application. However, high variability in the broadcast treatment likely masked treatment effects compared with incorporated band treatment. 


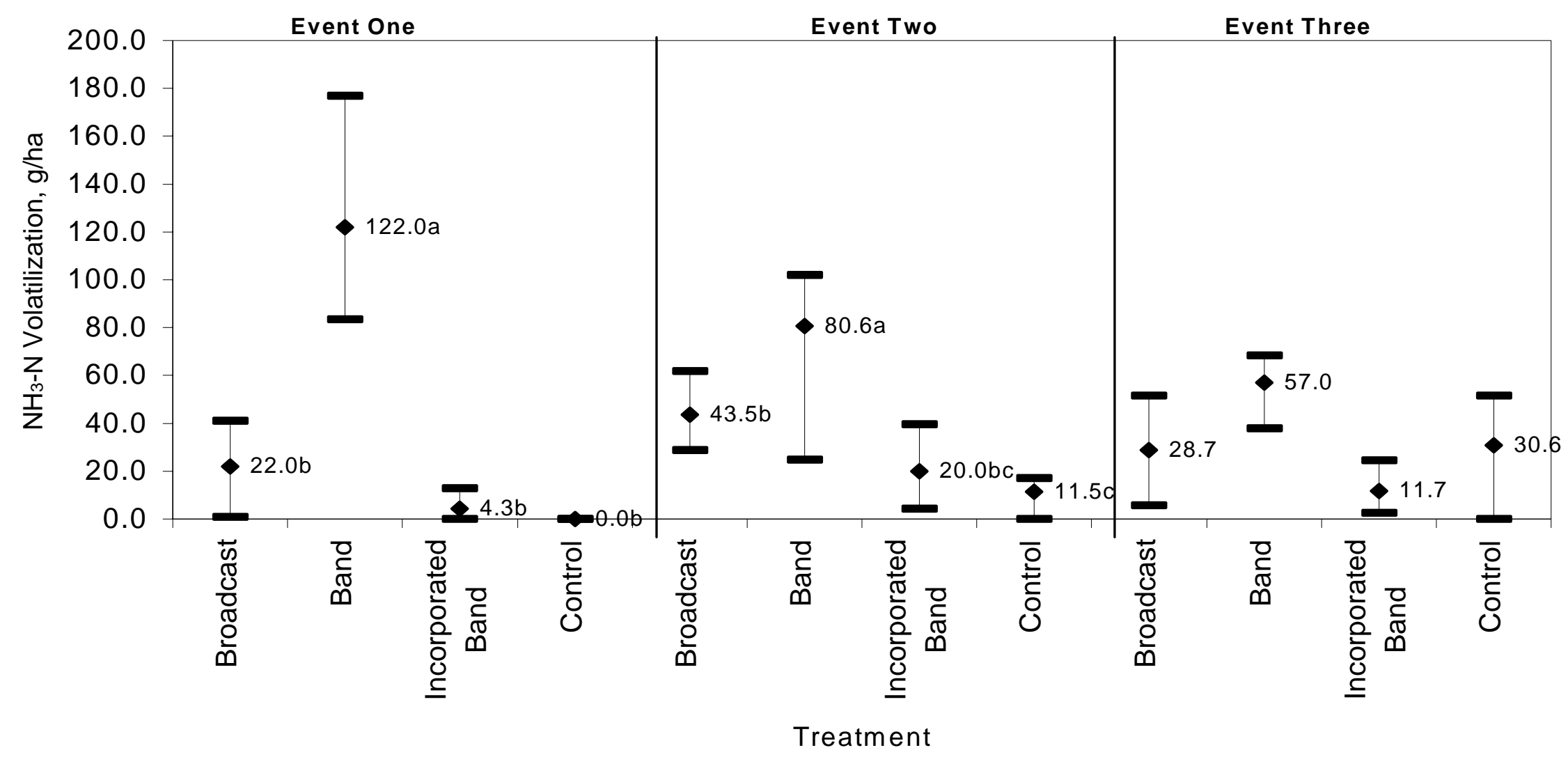

Figure 4.1. Ammonia volatilization during event one (0-6 h, 6-h duration), event two (6-24 h, $18-h$ duration), and event three (24-72 $h, 48-h$ duration). Mean values are based on three replications. Maximum and minimum values are indicated. Treatment impacts on $\mathrm{NH}_{3}$ volatilization were significant $(\alpha=0.05)$ for events one and two. Hence, for events one and two, treatment means in the same sampling event, followed by the same letter are not significantly different at $\alpha=0.05$ using Fisher's least significant difference (LSD) 
4.2.2. Event Two (6-24 h, 18 h duration)

Treatment impact on $\mathrm{NH}_{3}$ volatilization during event 2 is given in Figure 4.1. The treatments were significantly different (ANOVA $p=<0.01 ; \alpha=0.05$ ). Statistical outputs are presented in Appendix B.

Band application resulted in significantly higher $\mathrm{NH}_{3}$ volatilization losses (LSD $=27.7$ $\mathrm{g} / \mathrm{ha}$ ) than the other treatments. While the broadcast and control treatments were significantly different, the incorporated band treatment was not significantly different than the broadcast and control treatments. While reasons for higher $\mathrm{NH}_{3}$ losses from the band treatment are discussed earlier, high variability in the broadcast and incorporated band treatments likely masked treatment differences.

During this sampling event, raindrop splashing caused soil and possibly, turkey litter particles to be splashed onto the glass fiber filter, possibly, causing some contamination. However, soil and litter were likely to have caused very little ammoniacal-N to be deposited on the glass fiber filter.

\subsubsection{Event Three (24-72 h, 48 h duration)}

Treatment impact on $\mathrm{NH}_{3}$ volatilization during event 3 is given in Figure 4.1. The treatments were not significantly different (ANOVA $p=0.13 ; \alpha=0.05$ ). Statistical outputs are presented in Appendix B.

Runoff due to natural rainfall $(5.3 \mathrm{~cm})$ during this sampling event likely transported $\mathrm{NH}_{3}$ into the soil as well as in runoff, and hence, reduced $\mathrm{NH}_{3}$ available for volatilization. Splashing due to raindrop impact possibly caused some contamination of the filter paper with ammoniacal $\mathrm{N}$ from the soil and possibly, turkey litter. Treatment effects on $\mathrm{NH}_{3}$ volatilization could have 
been masked by high within-treatment variability. The reasons for comparable $\mathrm{NH}_{3}$ volatilization from the control treatment that received no turkey litter and the turkey litter treatments were unclear, however mineralization of wheat stalk on the soil surface may have produced some $\mathrm{NH}_{3}$.

\subsubsection{Event Four ( $72-120$ h, 48 h duration)}

Treatment impact on $\mathrm{NH}_{3}$ volatilization during event 4 is given in Figure 4.2. The treatments were not significantly different (ANOVA $p=0.06 ; \alpha=0.05$ ). Statistical outputs are presented in Appendix B. Lack of significant difference may be due to high within treatment variability.

\subsubsection{Event Five (120-168 h, 48 h duration)}

Treatment impact on $\mathrm{NH}_{3}$ volatilization during event 5 is given in Figure 4.2. The treatments were significantly different (ANOVA $p=0.02 ; \alpha=0.05$ ). Statistical outputs are presented in Appendix B.

Pairwise comparison indicated that broadcast and control treatments produced significantly higher $\mathrm{NH}_{3}$ volatilization losses $(\mathrm{LSD}=25.5 \mathrm{~g} / \mathrm{ha}$ ) than did band and incorporated band treatments. High $\mathrm{NH}_{3}$ volatilization losses so late in the study in the broadcast treatment were unexpected. Also unexpected was the high $\mathrm{NH}_{3}$ volatilization losses in the control treatment, though, mineralization of organic matter resulting in the release of $\mathrm{NH}_{3}$ could not be ruled out. Compared with the broadcast treatment, depletion of $\mathrm{NH}_{3}$ through both, volatilization (during the previous sampling event) and mineralization likely resulted in reduced $\mathrm{NH}_{3}$ losses in the band treatment. In the incorporated band treatment, conservation of ammoniacal- $\mathrm{N}_{\text {as }} \mathrm{NH}_{4}{ }^{+}$ 


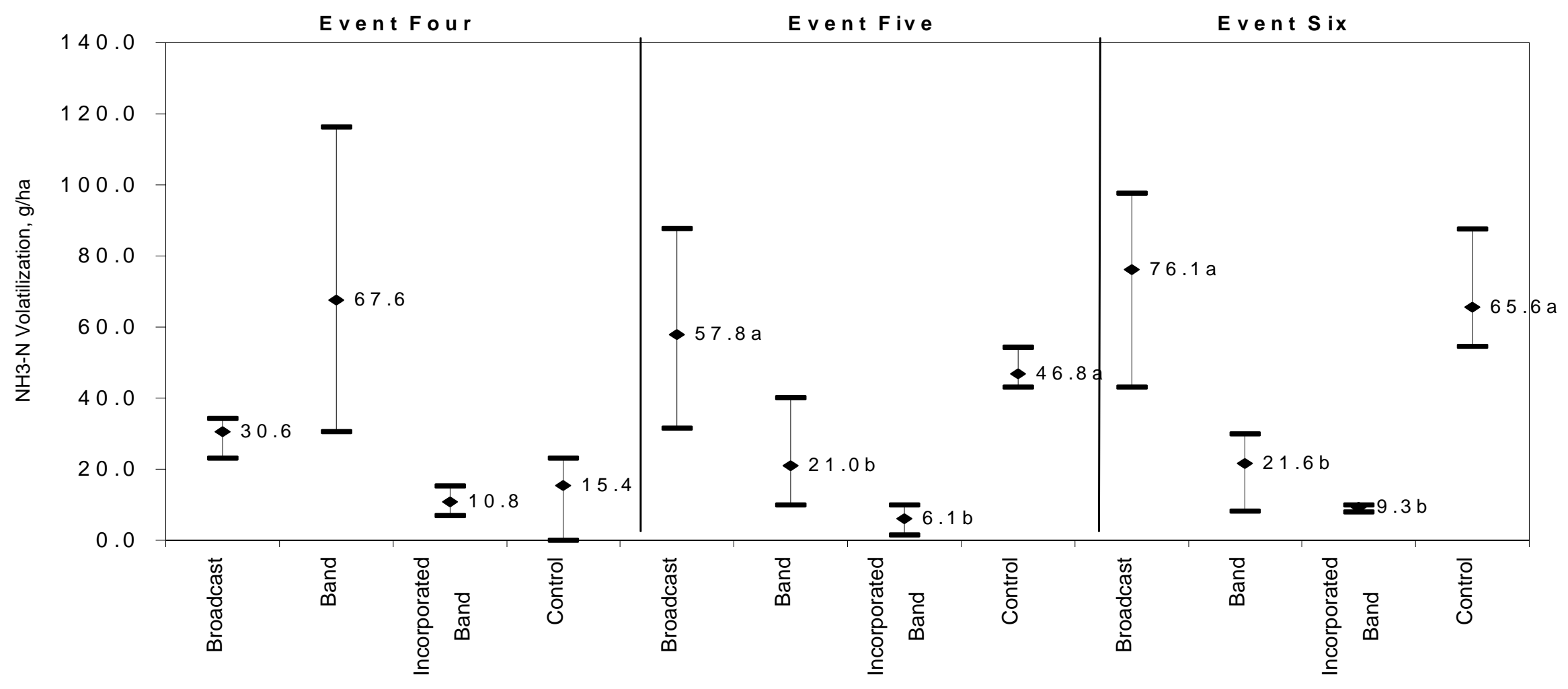

Treatm ent

Figure 4.2. Ammonia volatilization during event four (72-120 h, 48-h duration), event five (120-168 h, 48-h duration), and event six (168-216h, 48-h duration). Mean values are based on three replications. Maximum and minimum values are indicated. Treatment impacts on $\mathrm{NH}_{3}$ volatilization were significant $(\alpha=0.05)$ for events five and six. Hence, for events five and six, treatment means in the same sampling event, followed by the same letter are not significantly different at $\alpha=0.05$ using Fisher's least significant difference (LSD). 
as well as nitrification (as evidenced by high $\mathrm{NO}_{3}{ }^{-} \mathrm{N}$ loadings in the first simulated runoff event) likely contributed to low $\mathrm{NH}_{3}$ volatilization losses.

4.2.6. Event $\operatorname{Six}(168-216 \mathrm{~h}, 48 \mathrm{~h}$ duration)

Treatment impact on $\mathrm{NH}_{3}$ volatilization during event 4 is given in figure 4.2. The treatments were significantly different (ANOVA $p=<0.01 ; \alpha=0.05$ ). Statistical outputs are presented in Appendix B.

Pairwise comparisons indicated that the broadcast and control treatments produced significantly higher $\mathrm{NH}_{3}$ volatilization losses $(\mathrm{LSD}=27.8 \mathrm{~g} / \mathrm{ha}$ ) than did band and incorporated band treatments. It was unclear why the control treatment gave significantly higher $\mathrm{NH}_{3}$ loadings than band and incorporated band treatments, though mineralization of organic matter resulting in release of $\mathrm{NH}_{3}$ seemed a partial explaination.

\subsubsection{Event Seven $(216-264$ h, 48 h duration $)$}

Treatment impact on $\mathrm{NH}_{3}$ volatilization during event 7 is given in Figure 4.1. The treatments were significantly different (ANOVA $p=<0.01 ; \alpha=0.05$ ). Statistical outputs are presented in Appendix B.

As Figure 4.3 indicates, all treatments in event seven were significantly different (LSD = $10.7 \mathrm{~g} / \mathrm{ha}$ ) from each other. The control treatment produced the second highest $\mathrm{NH}_{3}$ losses, which was unexpected. However, compared with other treatments, the lowest $\mathrm{NH}_{3}$ loss in incorporated band treatment was expected. 


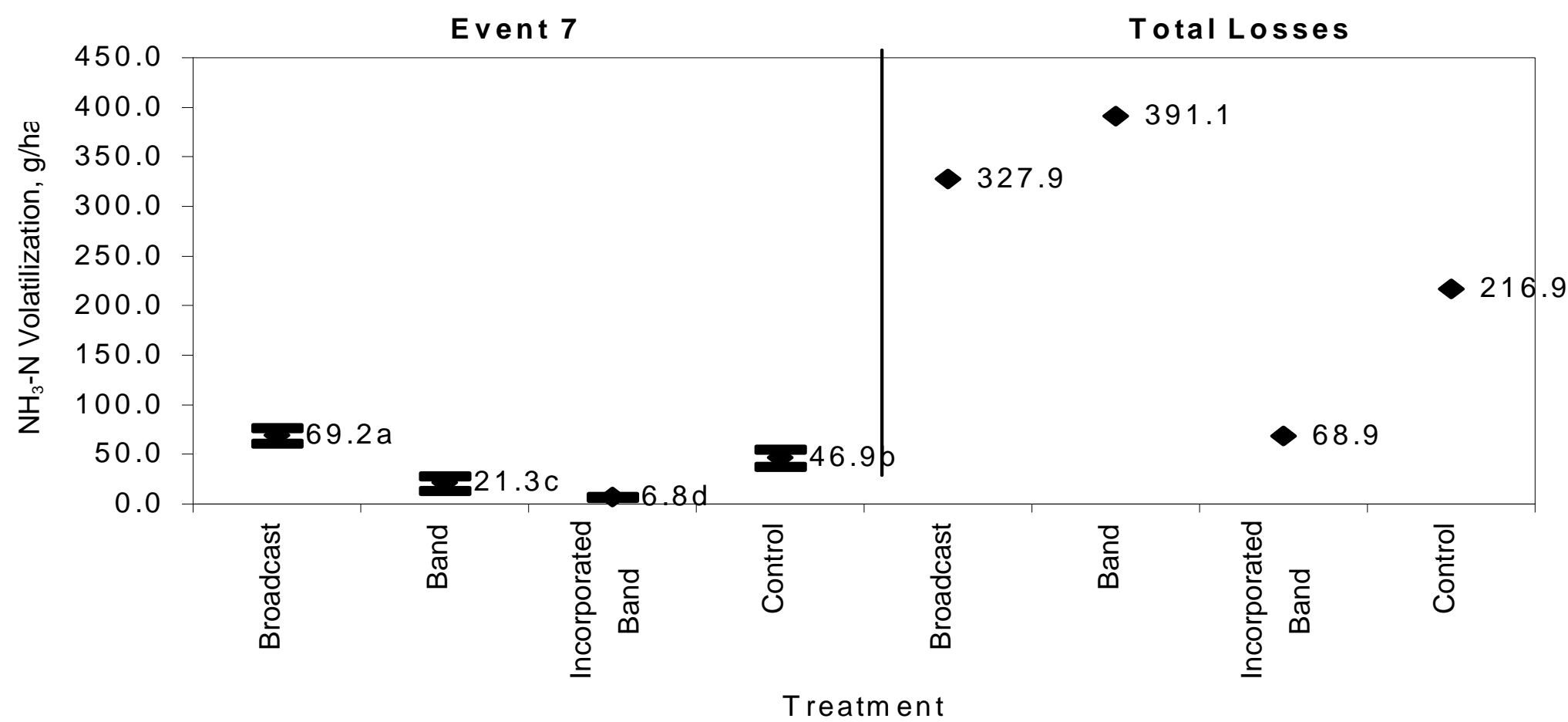

Figure 4.3. Ammonia volatilization during event seven (216-264 h, 48-h duration) and total $\mathrm{NH}_{3}$ volatilization losses. Maximum and minimum values are indicated for event seven. Treatment impacts on $\mathrm{NH}_{3}$ volatilization were significant $(\alpha=0.05)$ for event seven, hence, treatment means followed by the same letter are not significantly different at $\alpha=0.05$ using Fisher's least significant difference (LSD). Statistical analysis was not conducted to compare treatment impacts for total $\mathrm{NH}_{3}$ volatilization losses for the entire study duration. 


\subsubsection{Total Ammonia Volatilization Losses and Trends}

Total $\mathrm{NH}_{3}$ volatilization losses are presented in Figure 4.3. While the reasons for high $\mathrm{NH}_{3}$ volatilization losses in the band and broadcast applications could be explained, reasons for comparatively high $\mathrm{NH}_{3}$ volatilization losses in the control treatment $(>3$ times greater than the incorporated band treatment) were unclear. Incorporation of both turkey litter and residue into the soil in the incorporated band treatment likely resulted in conservation of $\mathrm{NH}_{3}$ due to conversion to $\mathrm{NH}_{4}{ }^{+}$and then to $\mathrm{NO}_{3}{ }^{-}$resulting in reduced $\mathrm{NH}_{3}$ volatilization.

Ammonia loss trend for the study duration is presented in Figure 4.4. Typical ammonia loss curves exhibit large losses soon after application and quickly decrease to low, steady levels. Banded and incorporated band treatments exhibited somewhat typical ammonia loss trends.

Broadcast and control treatments exhibited unexpected ammonia loss trends. However, ammonia loss trends from broadcast and control treatments were similar.

Trapping efficiency of the ammonia sampler, calculated using Equation [3.1.], is presented in Table 4.9. When trapping efficiency is taken into consideration, the $\mathrm{NH}_{3}$ volatilization losses become more than 10 times greater than measured losses. 


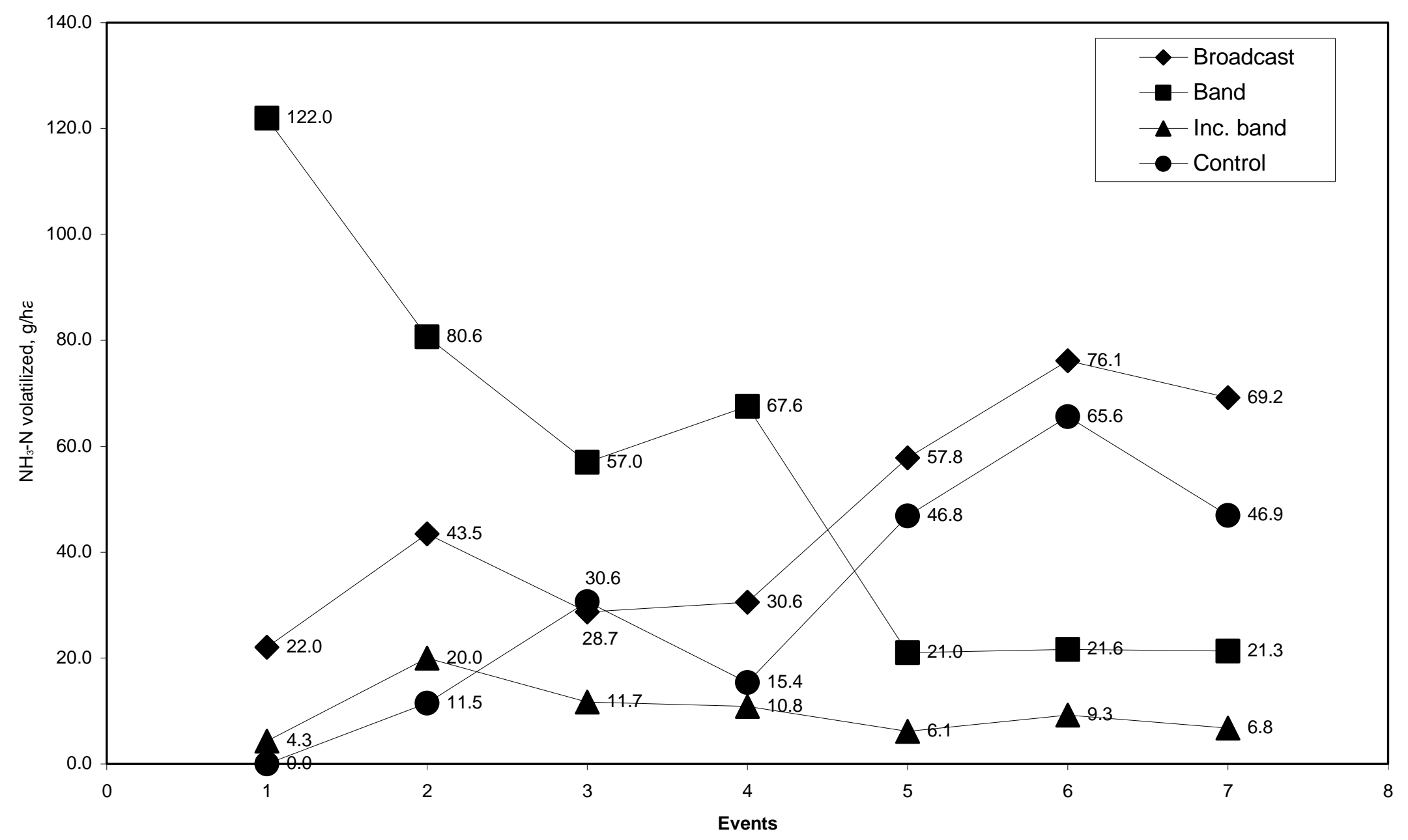

Figure 4.4. Ammonia loss trend for duration of $\mathrm{NH}_{3}$ volatilization study 
Table 4.9. Efficiency of $\mathrm{NH}_{3}$ Samplers ${ }^{[\mathrm{a}]}$

\begin{tabular}{lll}
\hline Sampling event & $\begin{array}{l}\text { Duration of sampling after } \\
\text { turkey litter application }(\mathrm{h})\end{array}$ & $\mathrm{NH}_{3}$ trapping efficiency \\
\hline 1 & $0-6 \mathrm{~h}$ & $23.5 \%{ }^{[\mathrm{b}]}$ \\
2 & $18-24 \mathrm{~h}$ & $10.7 \%$ \\
3 & $24-72 \mathrm{~h}$ & $1.7 \%$ \\
$4^{[\mathrm{c}]}$ & $72-120 \mathrm{~h}$ & $3.3 \%$ \\
$6^{[\mathrm{c}]}$ & $120-168 \mathrm{~h}$ & $14.1 \%$ \\
Full period $^{[\mathrm{d}]}$ & $168-216 \mathrm{~h}$ & $18.0 \%$ \\
\hline
\end{tabular}

${ }^{[\mathrm{a}]}$ Mean efficiency based on three replications, except where noted.

${ }^{\text {[b] }}$ Based on $\mathrm{NH}_{3}-\mathrm{N}$ in $20 \mathrm{~mL}$ of $\mathrm{NH}_{4} \mathrm{OH}$.

${ }^{[c]}$ Means based on two samples.

${ }^{[\mathrm{d}]}$ Total mean was weighted based on a $11 \mathrm{~d}$ sampling event.

Since a positive correlation exists between $\mathrm{NH}_{3}$ volatilization and temperature, lower temperatures in the ammonia samplers (during sunlight hours) could have reduced volatilization losses (see Figure 4.5.). It was observed that with cloud cover, temperature difference outside and inside the samplers were reduced, hence it was likely that temperature differences were lower during night than during daylight hours. 


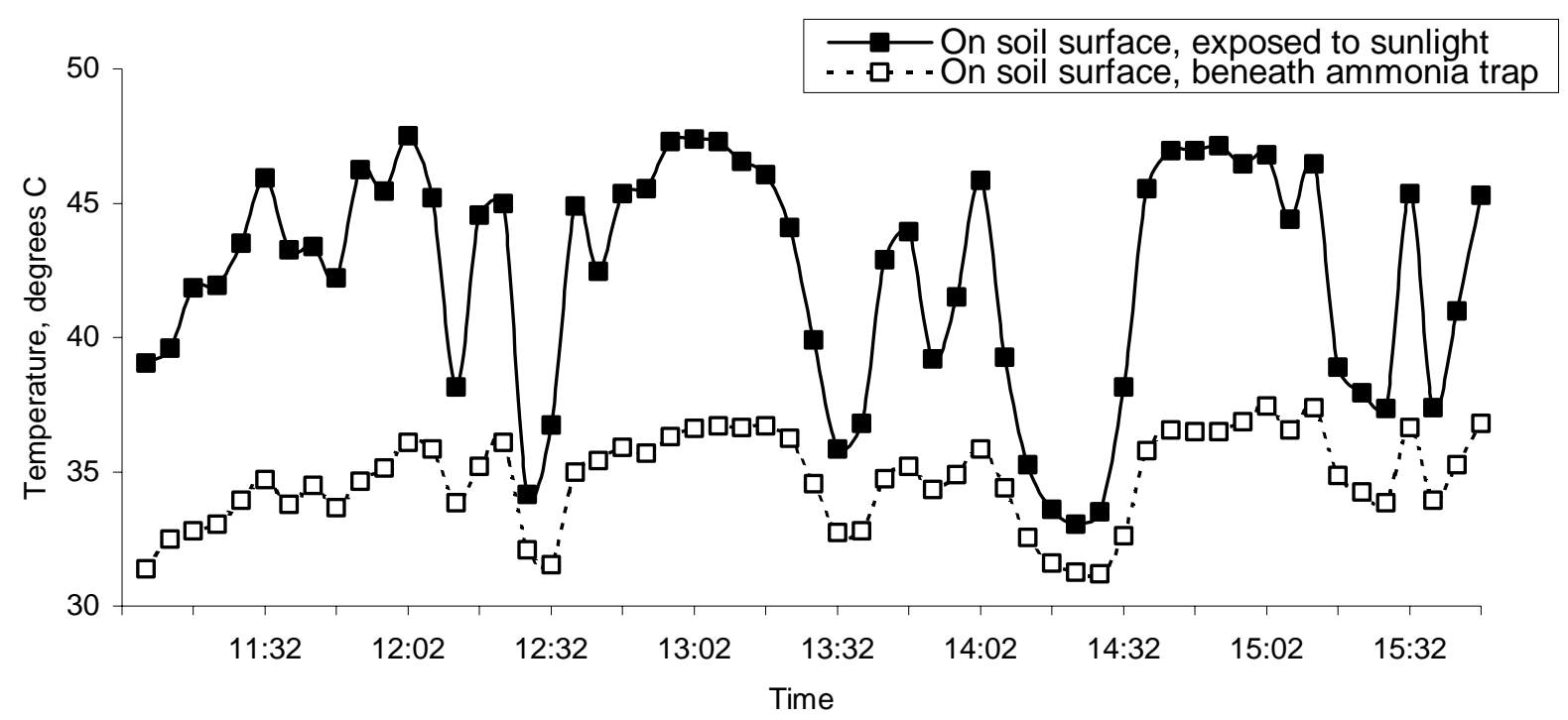

Figure 4.5. Soil surface temperature under ammonia sampler and exposed to sunlight

4.3 Environmental Impacts of Turkey Litter Application

In the water quality study, no significant differences between the treatments were observed. However, based on mean values and total losses, some differences in nutrient losses were observed among treatments. Incorporated band treatment resulted in lower ammoniacal $-\mathrm{N}$ and DRP loadings than other treatments. Also, broadcast and band treatments produced approximately two times higher TSS as the incorporated band treatment. Broadcast application and incorporated band application exhibited lower SBRP and TP than did the band treatment.

In the $\mathrm{NH}_{3}$ volatilization study, banded application consistently produced greater $\mathrm{NH}_{3}$ losses than other treatments early in the study; beginning event 5, broadcast application resulted in higher $\mathrm{NH}_{3}$ volatilization losses. Incorporated band application produced the lowest total $\mathrm{NH}_{3}$ losses. Broadcast and band application had five times more $\mathrm{NH}_{3}$ volatilization losses than the incorporated band application. 


\section{Chapter 5}

\section{Summary and Conclusions}

The environmental impacts of three turkey litter application methods, namely, broadcasting, banding, and incorporated banding of turkey litter were compared with respect to runoff water quality and ammonia volatilization. A control treatment was included to evaluate the impact of background nutrients on water quality and ammonia volatilization.

Turkey litter was applied to plots at $4500 \mathrm{~kg} / \mathrm{ha}$ basis. Runoff water quality was evaluated for a natural rainfall event as well as two simulated rainfall events. Runoff water volume was measured and examined for the following constituents: $\mathrm{NO}_{3}{ }^{-} \mathrm{N}$, ammoniacal - N, TKN, TP, SBRP, DRP, and TSS. All treatments were applied in triplicate.

The water quality study provided the following results.

1. At $\alpha=0.05$, the treatments were not significantly different with respect to loadings of any of the constituents.

2. Totaled over the three runoff events, incorporated banding produced substantially lower total loadings of ammoniacal - N, DRP and TSS than the broadcast and band treatments.

Ammonia volatilization losses were compared among treatments using passive samplers for seven sampling events over $11 \mathrm{~d}$. Ammonia trapping efficiency was evaluated using a reference sampler. 
The $\mathrm{NH}_{3}$ volatilization study provided the following results.

1. In five (events $1,2,5,6,7$ ) of seven sampling events where treatment impact was statistically significant, the banding treatment had the highest $\mathrm{NH}_{3}$ volatilization losses in the first two events. The broadcast and control treatments resulted in the highest $\mathrm{NH}_{3}$ volatilization losses in events 5 and 6 while the broadcast treatment had the highest $\mathrm{NH}_{3}$ volatilization losses in the last event.

2. As expected, $\mathrm{NH}_{3}$ volatilization loss in the incorporated band treatment was lower in three of five sampling events when a treatment impact on $\mathrm{NH}_{3}$ volatilization was significant.

3. Overall, totaled over the entire study period, $\mathrm{NH}_{3}$ losses were five times lower for the incorporated band treatment than the other turkey litter application methods.

4. The $\mathrm{NH}_{3}$ trapping efficiency of the sampler was low, at $8.2 \%$.

The overall conclusion of this study was that the incorporated band treatment offered the potential to reduce ammoniacal $-\mathrm{N}$ and DRP losses in runoff and $\mathrm{NH}_{3}$ volatilization losses. Further research should be conducted to better evaluate incorporated band vs. broadcast treatments in a cropped situation for both crop yield and water quality. 


\section{References}

Bittman, S., C.G. Kowalenko, D. E. Hunt, and O. Schmidt (1999). Surface- Banded and Broadcast Dairy Manure Effects on Tall Fescue Yield and Nitrogen Uptake. Agronomy Journal, 91, 826-823.

Black, A.S., R.R. Sherlock, K.C. Cameron, N.P. Smith and K.M. Goh (1985). Comparison of Three Field Methods for Measuring Ammonia Volatilization from Urea Granules Broadcast on to Pasture. Journal of Soil Science, 36, 271-280.

Cabrera, M.L., S.C. Tyson, T.R. Kelley, O.C. Pancorbo, W.C. Merka, and S.A. Thompson (1994). Nitrogen Mineralization and Ammonia Volatilization from Fractionated Poultry Litter. Soil Science Society of America, 58, 367-72.

Cabrera, M.L., S.C. Chiang, WW. C. Merka, S.A. Thompson, and O.C. Pancorbo (1993). Nitrogen Transformation in Surface Applied Poultry Litter: Effect of Litter Physical Characteristics. Soil Science Society of America Journal, 57, 1519-25.

Collins, E.R., J.C. Barker, L.E. Carr, H.L. Brodie, J.H. Martin, Jr. (1999). Poultry Waste Management Handbook, NRAES-132. Ithaca, NY: Natural Resource, Agriculture, and Engineering Service (NRAES).

Edwards, D.R. and T.C. Daniel (1992). Potential Runoff Quality Effects of Poultry Manure Slurry Applied to Fescue Plots. Transactions of the ASAE, 35(6), 1827-32.

Ferguson, F.B. (1997, October 17). Threat to the 'Nation's River'. The Charleston Gazette. Retrieved November 6, 2002, from http://www.wvgazette.com/static/series/poultry/ poul1012.html 
Gallimore, L.E., N.T. Basta, D.E. Storm, M.E. Payton, R.H. Huhnke, and M.D.Smolen (1999). Water Treatment Residual To Reduce Nutrients in Surface Runoff From Agricultural Land. Journal of Environmental Quality, 28(5), 1474-1478.

Hays, S.M. (1994). A cleanup for Poultry Litter. Agricultural Research, 42(5), 10

Humphry, J.B., T.C. Daniel, D.R. Edwards, and A.N. Sharpley (2002). A Portable Rainfall Simulator for Plot-Scale Runoff Studies. Applied Engineering in Agriculture, 18(2), 199204.

Innes, R. (1999). The Economics of Livestock Waste and Its Regulation. American Journal of Agricultural Economics, 82(1), 97.

Keppel, G. (1982). Design and Analysis: A Researcher's Handbook (2 ${ }^{\text {nd }}$ ed.). New Jersey: Prentice-Hall.

Marshal, S., C.W. Wood, E. Guertal (1998). Up, Up, and Away? Ammonia Loss to Atmosphere Studied [electronic version] Highlights of Agricultural Research. Alabama Agricultural Experiment Station and Auburn University.

Moore, P.A. Jr., T.C. Daniel, and D.R. Edwards (1999). Reducing Phosphorus Runoff and Improving Poultry Production with Alum. University of Arkansas: Agronomy Department.

Nichols, D.J., Daniel, T.C., and D.R. Edwards (1994). Nutrient Runoff from Pasture after Incorporation of Poultry Litter or Inorganic Fertilizer. Soil Science Society of America Journal, 58, 1224-1228.

Nommik, H. (1973). The Effect of Pellet Size on the Ammonia Loss from Urea Applied to Forest Soil. Plant and Soil, 39, 309-318. 
Rebaud, N.E., T.A. James, L. L. Ashbaugh, and R. G. Flocchini (2001). A

Passive Ammonia Sampler for the Determination of Airborne Ammonia Concentrations Near Large Scale Animal Facilities. Environmental Science and Technology, 35(6), 1190-1196.

Shelton, C.H., R.D. von Bernuth, and S.P. Rajbhandari (1985). A Continuous-Application Rainfall Simulator. Transactions of the ASAE, 28(4) 1115-1119.

Soil Conservation Service (SCS) (1982). Soil Survey of Marion and Monongalia Counties West Virginia. Morgantown: USDA - SCS.

Wood, B.H., C.W. Wood, K.H.Yoo, K.S. Yoon, and D.P.Delaney (1996). Nutrient Accumulation and Nitrate Leaching Under Broiler Litter Amended Corn Fields. Communications in Soil Science and Plant Analysis, 27(15), 2875-2894.

WVASS. 2002. West Virginia Agricultural Statistics Service (WVASS), c/o State Dept. Of Agriculture, Charleston, WV 25305. (URL: http://www.nass.usda.gov/wv/pltpdi01.pdf) Xingguo, Han and Wolf C. Duane. (1996) Phosphorus Availability in Two Soils Amended with Poultry Litter. Journal of Environmental Sciences, 8(4), 483-490. 


\section{Appendix A}

\section{Constituent Concentrations}

in Runoff 
Table A1 Runoff Constituent Concentrations for Natural Runoff

\begin{tabular}{|c|c|c|c|c|c|c|c|c|c|}
\hline \multirow{2}{*}{\multicolumn{2}{|c|}{ Plot Treatment }} & Runoff vol., & \multicolumn{7}{|c|}{ Concentration, $\mathrm{mg} / \mathrm{L}$} \\
\hline & & $\mathrm{L}$ & Nitrate-N & Ammonia-N & TKN & Total-P & DRP & SBRP & TSS \\
\hline 1 & Broadcast & 1.27 & bd & 2.12 & 109.50 & 5.66 & 0.27 & 0.79 & 274 \\
\hline 2 & Broadcast & 3.26 & 0.02 & 2.63 & 139.50 & 6.70 & 0.55 & 1.23 & 102 \\
\hline 3 & Band & 0.7 & 0.10 & $0.6 \varepsilon$ & 51.39 & 2.56 & 0.77 & 0.11 & 320 \\
\hline 4 & Band+inc & 0.5 & 0.12 & 0.21 & 78.43 & 1.11 & 0.32 & 0.20 & 62 \\
\hline 5 & Band+inc & 1 & 0.16 & 0.23 & 77.99 & 2.52 & 0.40 & 0.14 & 68 \\
\hline 6 & Control & 2.21 & 0.09 & 0.05 & 75.20 & 1.91 & 0.38 & 0.14 & 70 \\
\hline 7 & Broadcast & 1.15 & 0.02 & 2.26 & 25.80 & 4.01 & 0.22 & 1.17 & 116 \\
\hline 8 & Control & 0.9 & 0.12 & $0.1<$ & 70.89 & 1.74 & 0.20 & 0.11 & 72 \\
\hline 9 & Band+inc & 0.6 & 0.09 & 0.02 & 51.78 & 2.08 & 0.30 & 0.06 & 90 \\
\hline 10 & Band & 1.45 & 0.03 & $2.9 \varsigma$ & 109.40 & 5.06 & 0.76 & 0.81 & 172 \\
\hline 11 & Control & 5.75 & 0.01 & 0.15 & 65.50 & 0.74 & 0.24 & 0.02 & 100 \\
\hline 12 & Band & 3.1 & 0.03 & 2.35 & 72.47 & 4.15 & 0.87 & 0.50 & 150 \\
\hline
\end{tabular}

Table A2 Runoff Constituent Concentrations for Simulated Runoff Event 1

\begin{tabular}{llrlrrrrrr}
\hline & & Runoff vol., & \multicolumn{10}{c}{ Concentration, mg/L } \\
\cline { 3 - 10 } Plot & Treatment & L & Nitrate-N & Ammonia-N & TKN & Total-P & DRP & SBRP & TSS \\
\hline & & & & & & & & & \\
1 & Broadcast & 23.75 & 0.07 & 1.21 & 10.04 & 1.62 & 1.76 & 0 & 94 \\
2 & Broadcast & 40 & 0.08 & 1.13 & 8.09 & 1.35 & 2.18 & 0 & 102 \\
3 & Band & 13.9 & 0.03 & 1.68 & 10.98 & 2.86 & 3.01 & 0.33 & 122 \\
4 & Band+inc & 5.2 & 0.10 & 0.21 & 20.37 & 0.14 & 0.10 & 0.01 & 70 \\
5 & Band+inc & 29 & 0.15 & 0.26 & 19.76 & 3.03 & 0.45 & 0.02 & 74 \\
6 & Control & 36 & 0.06 & 0.02 & 8.51 & 0.28 & 0.27 & 0.01 & 110 \\
7 & Broadcast & 14.75 & 0.19 & 1.02 & 11.35 & 3.75 & 1.76 & 0.06 & 120 \\
8 & Control & 28.6 & 0.10 & 0.07 & 10.31 & 2.00 & 0.27 & 0.02 & 106 \\
9 & Band+inc & 17.45 & 0.41 & 1.29 & 13.43 & 4.20 & 1.07 & 0.66 & 102 \\
10 & Band & 27 & 0.00 & 2.83 & 16.60 & 9.15 & 5.01 & 1.76 & 88 \\
11 & Control & 32.3 & 0.10 & 0.12 & 9.09 & 1.88 & 0.40 & 0.02 & 112 \\
12 & Band & 21.1 & NA & NA & NA & NA & NA & NA & NA \\
\hline
\end{tabular}


Table A3 Runoff Constituent Concentrations for Simulated Runoff Event Two

\begin{tabular}{|c|c|c|c|c|c|c|c|c|}
\hline \multirow[b]{2}{*}{ Plot } & \multirow[b]{2}{*}{ Treatment } & Runoff vol., & \multicolumn{6}{|c|}{ Concentration, $\mathrm{mg} / \mathrm{L}$} \\
\hline & & $\mathrm{L}$ & Nitrate-N & Ammonia-N & TKN & Total-P DRP & SBRP & TSS \\
\hline 1 & Broadcast & 6.8 & 0.17 & $0.0 \varsigma$ & 7.712 & 0.2740 .33 & 0.00 & 20 \\
\hline 2 & Broadcast & 5.1 & 0.31 & 0.16 & 7.169 & 1.070 .49 & 0.03 & 78 \\
\hline 3 & Band & 2.9 & 0.13 & 0.05 & 516.068 & 1.360 .38 & 0.05 & 58 \\
\hline 4 & Band+inc & 3.65 & 0.08 & 0.05 & $5 \quad 6.852$ & 0.720 .25 & 0.01 & 0 \\
\hline 5 & Band+inc & 19.45 & 0.23 & 0.03 & 14.5 & 1.50 .24 & 0.02 & 0 \\
\hline 6 & Control & 17.4 & 0.20 & 0.03 & 6.661 & 0.7020 .19 & 0.02 & 76 \\
\hline 7 & Broadcast & 19.65 & 0.39 & $0.0 \varepsilon$ & 310.565 & 0.3260 .39 & 0.02 & 8 \\
\hline 8 & Control & 14.75 & 0.22 & 0.05 & 57.462 & 1.390 .21 & 0.01 & 0 \\
\hline 9 & Band+inc & 19.5 & 0.55 & 0.12 & 8.061 & 1.680 .37 & 0.01 & 0 \\
\hline 10 & Band & 21.55 & 0.53 & $0.1 \mathrm{~s}$ & 6.655 & 0.5360 .60 & 0.01 & 0 \\
\hline 11 & Control & 38.1 & 0.21 & 0.05 & 3.384 & 1.360 .23 & 0.02 & 0 \\
\hline 12 & Band & 14.65 & 0.47 & 0.10 & 6.609 & 0.8861 .00 & 0.07 & 0 \\
\hline
\end{tabular}


Appendix B

Statistical Outputs 
Table B1 Statistical Output of Runoff Volume for the Natural Runoff Event Sum of Squares df $\quad$ Mean Square $F \quad$ Sig.

\begin{tabular}{lrrrrr} 
Between Groups & 7.647158333 & 3 & 2.549052778 & 1.099089 & 0.404101 \\
Within Groups & 18.55393333 & 8 & 2.319241667 & & \\
Total & 26.20109167 & 11 & & & \\
\hline
\end{tabular}

Table B2 Statistical Output of $\mathrm{NO}_{3}^{-}-\mathrm{N}$ for the Natural Runoff Event

\begin{tabular}{lcrlll}
\hline & Sum of Squares df & & Mean Square & $F$ & Sig. \\
\hline Between Groups & 0.419388245 & 3 & 0.139796082 & 2.433019 & 0.139971 \\
Within Groups & 0.459662982 & 8 & 0.057457873 & & \\
Total & 0.879051227 & 11 & & & \\
\hline
\end{tabular}

Table B3 Statistical Output of Ammoniacal - $N$ for the Natural Runoff Event

\begin{tabular}{lrrrrr}
\hline & Sum of Squares df & & Mean Square & $F$ & Sig. \\
\hline Between Groups & 1264.640855 & 3 & 421.5469518 & 2.864753 & 0.103988 \\
Within Groups & 1177.196 & 8 & 147.1495 & \\
Total & 2441.836856 & 11 & & & \\
\hline
\end{tabular}

Table B4 Statistical Output of TKN for the Natural Runoff Event

\begin{tabular}{lrrrrr}
\hline & Sum of Squares df & & Mean Square & $F$ & Sig. \\
\hline Between Groups & 1221799.496 & 3 & 407266.4986 & 0.776132 & 0.539388 \\
Within Groups & 4197910.391 & 8 & 524738.7989 & & \\
Total & 5419709.887 & 11 & & & \\
\hline
\end{tabular}


Table B5 Statistical Output of TP for the Natural Runoff Event

\begin{tabular}{lrrrrr}
\hline & Sum of Squares df & & Mean Square & $F$ & Sig. \\
\hline Between Groups & 4249.319773 & 3 & 1416.439924 & 1.882175 & 0.210996 \\
Within Groups & 6020.439744 & 8 & 752.554968 & & \\
Total & 10269.75952 & 11 & & & \\
\hline
\end{tabular}

Table B6 Statistical Output of DRP for the Natural Runoff Event

\begin{tabular}{lrrrrr}
\hline & Sum of Squares df & & Mean Square & $F$ & Sig. \\
\hline Between Groups & 54.11487523 & 3 & 18.03829174 & 1.21317 & 0.365828 \\
Within Groups & 118.9498508 & 8 & 14.86873135 & & \\
Total & 173.0647261 & 11 & & & \\
\hline
\end{tabular}

Table B7 Statistical Output of SBRP for the Natural Runoff Event

\begin{tabular}{lrrrrr}
\hline & Sum of Squares df & & Mean Square & F & Sig. \\
\hline Between Groups & 198.6034142 & 3 & 66.20113808 & 3.198654 & 0.083739 \\
Within Groups & 165.572505 & 8 & 20.69656313 & & \\
Total & 364.1759192 & 11 & & & \\
\hline
\end{tabular}

Table B8 Statistical Output of TSS for the Natural Runoff Event

\begin{tabular}{lrrrrr}
\hline & Sum of Squares df & \multicolumn{1}{c}{ Mean Square } & $F$ & Sig. \\
\hline Between Groups & 3128641.75 & 3 & 1042880.583 & 1.568551 & 0.271124 \\
Within Groups & 5318950.187 & 8 & 664868.7733 & & \\
Total & 8447591.937 & 11 & & & \\
\hline
\end{tabular}


Table B9 Statistical Output of Runoff Volume for Simulated Runoff Event 1

\begin{tabular}{lccccc}
\hline & Df & Sum of Squares & Mean Square & F & Sig. \\
\hline Between Groups & 3 & 392.036 & 130.679 & 1.443 & 0.301 \\
Within Groups & 8 & 724.310 & 90.539 & 1.443 & \\
Total & 11 & 1116.346 & & & \\
\hline
\end{tabular}

Table B10 Statistical Output of $\mathrm{NO}_{3}^{-}-\mathrm{N}$ for Simulated Runoff Event 1

\begin{tabular}{lccccc}
\hline & Df & Sum of Squares & Mean Square & F & Sig. \\
\hline Model & 3 & 419.510067 & 139.836689 & 1.65 & 0.2629 \\
Error & 7 & 592.815733 & 84.687962 & & \\
Corrected Total & 10 & 1012.325800 & & & \\
\hline
\end{tabular}

Table B11 Statistical Output of Ammoniacal - N for Simulated Runoff Event 1

\begin{tabular}{lccccc}
\hline & Df & Sum of Squares & Mean Square & F & Sig. \\
\hline Model & 3 & 82069.6186 & 27356.5395 & 3.64 & 0.0724 \\
Error & 7 & 52634.1322 & 7519.1617 & & \\
Corrected Total & 10 & 134703.7508 & & & \\
\hline
\end{tabular}

Table B12 Statistical Output of TKN for Simulated Runoff Event 1

\begin{tabular}{lccccc}
\hline & Df & Sum of Squares & Mean Square & F & Sig. \\
\hline Model & 3 & 184744.165 & 61581.388 & 0.10 & 0.9575 \\
Error & 7 & 4311977.329 & 615996.761 & & \\
Corrected Total & 10 & 4496721.494 & & & \\
\hline
\end{tabular}


Table B13 Statistical Output of TP for Simulated Runoff Event 1

\begin{tabular}{lccccc}
\hline & Df & Sum of Squares & Mean Square & $F$ & Sig. \\
\hline Model & 3 & 372099.645 & 124033.215 & 1.26 & 0.3598 \\
Error & 7 & 690258.040 & 98608.291 & & \\
Corrected Total & 10 & 1062357.685 & & & \\
\hline
\end{tabular}

Table B14 Statistical Output of DRP for Simulated Runoff Event 1

\begin{tabular}{lccccc}
\hline & Df & Sum of Squares & Mean Square & F & Sig. \\
\hline Model & 3 & 254532.1986 & 84844.0662 & 3.61 & 0.0733 \\
Error & 7 & 164295.8720 & 23470.8389 & & \\
Corrected Total & 10 & 418828.0706 & & & \\
\hline
\end{tabular}

Table B15 Statistical Output of SBRP for Simulated Runoff Event 1

\begin{tabular}{lcrrrr}
\hline & Df & Sum of Squares & Mean Square & F & Sig. \\
\hline Model & 3 & 25080.24090 & 8360.08030 & 2.33 & 0.1612 \\
Error & 7 & 25148.54107 & 3592.64872 & & \\
Corrected Total & 10 & 50228.78196 & & & \\
\hline
\end{tabular}

Table B16 Statistical Output of TSS for Simulated Runoff Event 1

\begin{tabular}{lccccc}
\hline & Df & Sum of Squares & Mean Square & F & Sig. \\
\hline Model & 3 & 179575915.7 & 59858638.6 & 3.09 & 0.0993 \\
Error & 7 & 135784640.8 & 19397805.8 & & \\
Corrected Total & 10 & 315360556.5 & & & \\
\hline
\end{tabular}


Table B17 Statistical Output of Runoff Volume for Simulated Rainfall Event 2

\begin{tabular}{lrrrrr}
\hline & Sum of Squares & df & Mean Square & $F$ & Sig. \\
\hline & & & & & \\
Between Groups & 285.3241667 & & 395.10805556 & 0.953142 & 0.459915 \\
Within Groups & 798.27 & 8 & 99.78375 & & \\
Total & 1083.594167 & 11 & & & \\
\hline
\end{tabular}

Table B18 Statistical Output of $\mathrm{NO}_{3}^{-}-\mathrm{N}$ for Simulated Rainfall Event 2

\begin{tabular}{|c|c|c|c|c|c|}
\hline & Sum of Squares & $\mathrm{df}$ & Mean Square & $\mathrm{F}$ & Sig. \\
\hline Between Groups & 295.6232626 & & 398.54108754 & 0.199491 & 0.893856 \\
\hline Within Groups & 3951.70604 & & $8 \quad 493.963255$ & & \\
\hline Total & 4247.329303 & & 11 & & \\
\hline
\end{tabular}

Table B19 Statistical Output of Ammoniacal - $N$ for Simulated Rainfall Event 2

\begin{tabular}{lrrrrr}
\hline & Sum of Squares & df & Mean Square & $F$ & Sig. \\
\hline & & & & & \\
Between Groups & 45.0967955 & & 315.03226517 & 0.390706 & 0.763081 \\
Within Groups & 307.7970521 & 838.47463151 & & \\
Total & 352.8938476 & 11 & & & \\
\hline
\end{tabular}

Table B20 Statistical Output of TKN for Simulated Rainfall Event 2

\begin{tabular}{lrrrrr}
\hline & Sum of Squares & df & Mean Square & $F$ & Sig. \\
\hline Between Groups & 165919.8068 & & & & \\
Within Groups & 1394341.028 & 817429.60228 & 0.31732 & 0.81277 \\
Total & 1560260.834 & 11 & & \\
\hline
\end{tabular}


Table B21 Statistical Output of TP for Simulated Rainfall Event 2

\begin{tabular}{lrrrrr}
\hline & Sum of Squares & df & Mean Square & F & Sig. \\
\hline Between Groups & 26373.57518 & & 38791.191728 & 1.909825 & 0.206509 \\
Within Groups & 36825.11923 & & 84603.139904 & & \\
Total & 63198.69442 & & 11 & & \\
\hline
\end{tabular}

Table B22 Statistical Output of DRP for Simulated Rainfall Event 2

\begin{tabular}{lrrrrr}
\hline & Sum of Squares & df & Mean Square & $F$ & Sig. \\
\hline & & & & & \\
Between Groups & 1486.10851 & & 3495.3695033 & 0.942161 & 0.464453 \\
Within Groups & 4206.242171 & 8525.7802714 & & \\
Total & 5692.350681 & 11 & & & \\
\hline
\end{tabular}

Table B23 Statistical Output of SBRP for Simulated Rainfall Event 2

\begin{tabular}{|c|c|c|c|c|c|}
\hline & Sum of Squares & df & Mean Square & $\mathrm{F}$ & Sig. \\
\hline Between Groups & 4.636779167 & & 31.545593056 & 0.606108 & 0.629373 \\
\hline Within Groups & 20.40024583 & & 82.550030729 & & \\
\hline Total & 25.037025 & & 11 & & \\
\hline
\end{tabular}

Table B24 Statistical Output of TSS for Simulated Rainfall Event 2

\begin{tabular}{lrrrrr}
\hline & Sum of Squares & df & Mean Square & $F$ & Sig. \\
\hline & & & & & \\
Between Groups & 8872244.667 & & 32957414.889 & 0.771302 & 0.541754 \\
Within Groups & 30674525.33 & 83834315.667 & & \\
Total & 39546770 & 11 & & & \\
\hline
\end{tabular}


Table B25 Statistical Output of Ammonia Volatilization for Event 1

\begin{tabular}{lccccc}
\hline & df & Sum of Squares & Mean Square & F & Sig. \\
\hline Model & 3 & 29647.82000 & 9882.60667 & 13.86 & 0.0016 \\
Error & 8 & 5706.04667 & 713.25583 & & \\
Corrected Total & 11 & 35353.86667 & & & \\
\hline
\end{tabular}

Table B26 Statistical Output of Ammonia Volatilization for Event 2

\begin{tabular}{lccccc}
\hline & df & Sum of Squares & Mean Square & F & Sig. \\
\hline Model & 3 & 8617.88667 & 2872.62889 & 8.67 & 0.0068 \\
Error & 8 & 2652.15333 & 331.51917 & & \\
Corrected Total & 11 & 11270.04000 & & & \\
\hline
\end{tabular}

Table B27 Statistical Output of Ammonia Volatilization for Event 3

\begin{tabular}{lccccc}
\hline & df & Sum of Squares & Mean Square & F & Sig. \\
\hline Model & 3 & 3153.606667 & 1051.202222 & 2.51 & 0.1325 \\
Error & 8 & 3349.493333 & 418.686667 & & \\
Corrected Total & 11 & 6503.100000 & & & \\
\hline
\end{tabular}

Table B28 Statistical Output of Ammonia Volatilization for Event 4

\begin{tabular}{lccccc}
\hline & df & Sum of Squares & Mean Square & F & Sig. \\
\hline Model & 3 & 5961.98917 & 1987.32972 & 3.65 & 0.0635 \\
Error & 8 & 4355.00000 & 544.37500 & & \\
Corrected Total & 11 & 10316.98917 & & & \\
\hline
\end{tabular}


Table B29 Statistical Output of Ammonia Volatilization for Event 5

\begin{tabular}{lccccc}
\hline & df & Sum of Squares & Mean Square & F & Sig. \\
\hline Model & 3 & 5024.570000 & 1674.856667 & 5.94 & 0.0197 \\
Error & 8 & 2257.020000 & 282.127500 & & \\
Corrected Total & 11 & 7281.590000 & & & \\
\hline
\end{tabular}

Table B30 Statistical Output of Ammonia Volatilization for Event 6

\begin{tabular}{lccccc}
\hline & df & Sum of Squares & Mean Square & F & Sig. \\
\hline Model & 3 & 9606.56250 & 3202.18750 & 9.54 & 0.0051 \\
Error & 8 & 2686.36667 & 335.79583 & & \\
Corrected Total & 11 & 12292.92917 & & & \\
\hline
\end{tabular}

Table B31 Statistical Output of Ammonia Volatilization for Event 7

\begin{tabular}{lccccc}
\hline & df & Sum of Squares & Mean Square & F & Sig. \\
\hline Model & 3 & 6867.763333 & 2289.254444 & 46.37 & $<0.0001$ \\
Error & 8 & 394.926667 & 49.365833 & & \\
Corrected Total & 11 & 7262.690000 & & & \\
\hline
\end{tabular}


Appendix C

Definition of Terms 
Ammonia Volatilization- A mechanism of $\mathrm{N}$ loss to the atmosphere that occurs naturally in all soils.

Incorporated band- Application method in which litter is dribbled onto the soil surface in bands $10-15 \mathrm{~cm}$ wide, at $75 \mathrm{~cm}$ row spacing. Incorporation occurs immediately after application only in the banded area resulting in the mixture of soil with litter.

Leaching- The movement of dissolved solute with percolating water deeper into the soil profile.

Non-point source pollution- Air and water pollution sources that cannot be specifically identified as coming from discrete, unidentifiable points.

Runoff- Water movement along the soil surface occurring from precipitation and run on.

Poultry litter- A mixture of poultry excreta and bedding material such as sawdust, wood chips, peanut hulls, etc.

Slurry- A mixture of manure or litter with water to form a semi-liquid consistency.

Surface banding- Application method in which litter is dribbled onto the soil surface in bands 10$15 \mathrm{~cm}$ wide at $75 \mathrm{~cm}$ row spacing. 